\title{
Highly deformable and highly fluid vesicles as potential drug delivery systems: theoretical and practical considerations
}

This article was published in the following Dove Press journal:

International Journal of Nanomedicine

19 August 2013

Number of times this article has been viewed

\author{
Eder Lilia Romero \\ Maria Jose Morilla \\ Nanomedicine Research Program, \\ Department of Science and \\ Technology, National University \\ of Quilmes, Bernal, Buenos Aires, \\ Argentina
}

Correspondence: Eder Lilia Romero Programa de Nanomedicinas, Departamento de Ciencia y Tecnología, Universidad Nacional de Quilmes,

Roque Saenz Peña 352, Bernal, BI876 BXD, Buenos Aires, Argentina Tel +54 । | 43657 I00

Fax +54 | |43657| 32

Email elromero@unq.edu.ar

\begin{abstract}
Vesicles that are specifically designed to overcome the stratum corneum barrier in intact skin provide an efficient transdermal (systemic or local) drug delivery system. They can be classified into two main groups according to the mechanisms underlying their skin interaction. The first group comprises those possessing highly deformable bilayers, achieved by incorporating edge activators to the bilayers or by mixing with certain hydrophilic solutes. The vesicles of this group act as drug carriers that penetrate across hydrophilic pathways of the intact skin. The second group comprises those possessing highly fluid bilayers, owing to the presence of permeation enhancers. The vesicles of this group can act as carriers of drugs that permeate the skin after the barrier of the stratum corneum is altered because of synergistic action with the permeation enhancers contained in the vesicle structure. We have included a detailed overview of the different mechanisms of skin interaction and discussed the most promising preclinical applications of the last five years of Transfersomes ${ }^{\circledR}$ (IDEA AG, Munich, Germany), ethosomes, and invasomes as carriers of antitumoral and anti-inflammatory drugs applied by the topical route.
\end{abstract}

Keywords: Transfersomes, ethosomes, antitumoral, anti-inflammatory, topical delivery

\section{Introduction}

In 1964, Alec Bangham made the first description of liposomes as closed vesicles made of phospholipids, formed in an excess of water. ${ }^{1}$ Nearly one decade later, intravenously administered liposomes were first used as drug-delivery systems. ${ }^{2}$ In a simplistic approach, sterically stabilized liposomes injected into the vascular compartment, plus the presence of the enhanced permeation and retention effect, ensures the access and subsequent uptake of relatively intact liposomes by deep tissues. ${ }^{3}$ Currently, the structural engineering and targeting of intravenously administered liposomes has reached a plateau. ${ }^{4}$ On the other hand, the impaired penetration of topically-applied liposomes across the stratum corneum (SC) of intact skin has demanded the improvement of their bilayer design. Thus, at the beginning of the 1990s, the pioneering work of Gregor Cevc showed that, by modifying the chemical composition of bilayers so as to decrease its Young's modulus nearly tenfold below that of conventional liposomes, the resulting deformable liposomes could successfully penetrate the 10-20 $\mu \mathrm{m}$ thick barrier comprised of stacked corneocytes embedded in a non-phospholipid lipid matrix. ${ }^{5}$ Gaining access to the viable epidermis by overcoming the physical constraints imposed by the narrow imperfections of the lipid lamella of the SC requires specifically engineered liposomal bilayers.

This review is an update on vesicles that have unique structural properties that are aimed at increasing the delivery of drugs to skin cells and to local underlying muscle. 
Due to the controversies in classification discussed below, we have grouped the vesicles as having highly deformable bilayers or highly fluid bilayers. The first group is composed of vesicles of increased deformability (a synonym for elasticity/flexibility), such as Transfersomes ${ }^{\circledR}$ (IDEA AG, Munich, Germany) and flexible vesicles made of nonionic surfactants. The second group encompasses the ethosomes, invasomes, and penetration enhancer-containing vesicles. We will exclusively focus on the most promising preclinical and clinical therapeutic applications of the last five years, excluding the use of the topical route for vaccination and cosmetics uses.

\section{Highly deformable versus highly fluid vesicles: structure and mechanisms of skin interaction Transfersomes: the advantages of being deformable}

The first-generation of Transfersomes ${ }^{6}$ (TRS [recently reviewed $\left.^{7}\right]$ ) includes hydrophilic vesicles made of bilayer forming phospholipids plus a given amount of edge activators (EA) (surfactants/hydrophilic detergents of high mobility such as sodium cholate, sodium deoxycholate, Span 60, Span 65, Span 80, Tween 20, Tween 60, Tween 80, and dipotassium glycyrrhizinate). The second-generation of TRS is made of at least one basic bilayer builder, typically phosphatidylcholine with fluid-chains, and at least two more polar lipophilic substances, eg, one surfactant and one surfactant mimicking drug. ${ }^{8,9}$ Such vesicles have higher drug payload and/or carrier adaptability, but rely on similar bilayer ingredients and component-selection methods as the first-generation (Transfersome carriers, IDEA AG). Both are chiefly comprised of phospholipid-surfactant mixtures chosen via solubilization-assay.

As a response to the mechanical stress, the EA are demixed from the lipid bilayer and displaced to relocate in the zones of higher curvature/stress, whereas the more hydrophobic amphiphilic molecules enrich the bilayer regions with a smaller curvature. Such rearrangements are responsible for diminishing the membrane elastic energy and for forming TRS that are more deformable than conventional liposomes by up to five orders of magnitude. ${ }^{10}$ In other words, TRS can change shape and volume at minimal energetic cost. ${ }^{11}$ TRS possess high bilayer permeability and adapt their local bilayer composition to ambient stress. Because of this, TRS are said to behave as "molecular devices". ${ }^{12}$

TRS make use of the driving force generated by the transdermal osmotic gradient on the skin surface (from around $75 \%$ in the viable epidermis to $10 \%-30 \%$ at an air-exposed skin surface $)^{13}$ to spontaneously penetrate the intact skin across the $\mathrm{SC}$ to reach the viable epidermis. ${ }^{14-16}$ Such penetration exclusively occurs under nonocclusive conditions and is not mediated by diffusion, and is therefore independent of the concentration gradient of material. By representing the skin as an artificial nanoporous barrier, the penetration of vesicles is proportional to the pore density and inversely proportional to the membrane elastic energy. The minimal membrane elastic energy of TRS allows for the transport of as much as $>95 \%$ of the applied lipid mass into or through the normal SC of the murine skin. ${ }^{17}$ The estimated force of deformation of TRS is calculated as $\mathrm{F}_{\text {deformation }} \sim 500$ $\mathrm{pN}$, of similar order of magnitude as an ultradeformable vesicle insertion force $\left(\mathrm{F}_{\text {insertion }}=8-800 \mathrm{pN}\right)$, and below the force opposing partial bilayer dehydration. In contrast, less deformable conventional liposomes do not penetrate the intact mammalian skin to any significant extent, ${ }^{18}$ and have at least one order of magnitude higher insertion force above the threshold for bilayer dehydration $\left(\mathrm{F}_{\text {dehydration }} \sim 0.8-7 \mathrm{nN}\right)$ and fusion. Such vesicles collapse/fuse on the hydrophobic skin surface.

The skin has wide, relatively sparse $\left(10^{2}-10^{3} \mathrm{~cm}^{-2}\right)$ hydrophilic pathways (skin appendages, sweat ducts [>50 $\mu \mathrm{m}]$, pilosebaceous units $[5-70 \mu \mathrm{m}]$, and sebaceous glands [5-15 $\mu \mathrm{m}])$. At the end of the range, there are the more abundant $\left(10^{6}-10^{10} \mathrm{~cm}^{-2}\right)$ small width diffusion pathways, typically running within lipid layers for lipophilic molecules of high resistance ( $\leq 10 \mathrm{~nm}$ narrow inter-corneocyte pore junctions of corneocyte-clusters and cluster boundaries). ${ }^{19,20}$ Overall, hydrophilic pathways on the intact SC cover only a tiny $(<0.001 \%)$ fraction of the normal skin surface (whereas cutaneous blood vessels area exceeds skin surface by $2-5$ fold) and are 10-200 times narrower than the regular size of a TRS $(\sim 100 \mathrm{~nm}) .{ }^{19}$ Nonetheless, the TRS can overcome the skin barrier through these hydrophilic intercellular channels (and not across the lipophilic cutaneous barrier) that are too narrow to be penetrated by other kinds of lipid aggregate. ${ }^{21}$ It was speculated that TRS were capable of reaching the blood in intact form, but these results failed to be reproducible. ${ }^{22}$

In 2012, the idea of considering the average amphipathic area per chain (Ac) as a good predictive parameter of the elastomechanic properties of vesicles prepared from a special combination of molecules (Ac correlates, quasiexponentially, with the ease of bilayer vesicle formation and bilayer deformability) was launched. ${ }^{6}$ On this basis, the Ac was employed to define the third-generation of ultradeformable drug carriers, which exploit the adaptive 
redistribution of 'hydrophilic modulators' near a bilayer and that could functionally replicate the beneficial effects of bilayer-solubilizing lipophilic compounds (surfactants). In the first and second-generation TRS, such rearrangement took place within or across the mixed lipid bilayer. In the third-generation, water-soluble molecule redistribution near a bilayer surface was shown to be similarly effective. Hydrophilic modulators of bilayer properties can increase vesicle adaptability, stability, and/or drug payload. Examples of this could be novel antifungal preparations, surfactantor phospholipid-free nonsteroidal anti-inflammatory drug (NSAID) preparations, phospholipid free drug-carriers, etc. This includes bioactive hydrophilic and highly adaptable composite vesicles for drugless treatment of non-severe pain and inflammation involving physical mechanisms of action. $^{23,24}$

\section{Elastic vesicles from nonionic surfactants}

These are elastic (deformable) vesicles prepared from the bilayer-forming surfactant L-595 (100\% sucrose laurate ester, $30 \%$ mono-, $40 \%$ di-, and $30 \%$ triester) and the micelle-forming nonionic surfactant PEG-8-L (polyoxyethylene laurate ester) with sulfosuccinate as stabilizer (50/50/5 molar ratio). ${ }^{25}$ Vesicles facilitate drug transport by a fast partitioning into the SC, thereby carrying vesicle-bound drug molecules into the SC. ${ }^{26}$ The transport is via a fine meshwork of thread-like channels. The vesicles themselves remain in the SC and do not penetrate into the deeper skin layers. Drug molecules are then released from the vesicles, after which they can permeate into the deeper skin layers to reach the systemic circulation. ${ }^{27}$ Only mechanistic but not preclinical applications have been published to date.

\section{Ethosomes: the advantages of being fluid}

These are fluid vesicles prepared from phospholipids, a high proportion of the permeation enhancer ethanol, ${ }^{28,29}$ and water; typically $2 \%-5 \%$ phosphatidylcholine (PC), $20 \%-45 \%$ ethanol, and water to $100 \% \mathrm{w} / \mathrm{w} .{ }^{23,24}$ Figure 1 represents the main structural differences between TRS and ethosomes.

Ethanol, even at low concentrations, binds to the lipid polar heads and increases the fluidity of the liquid crystalline state. ${ }^{30,31}$ By employing Phosphorous-31 nuclear magnetic resonance (NMR) spectroscopy $\left(\mathrm{NMR}^{31} \mathrm{P}\right)$, the polar head group motions of $\mathrm{PC}$ were found to be restricted and

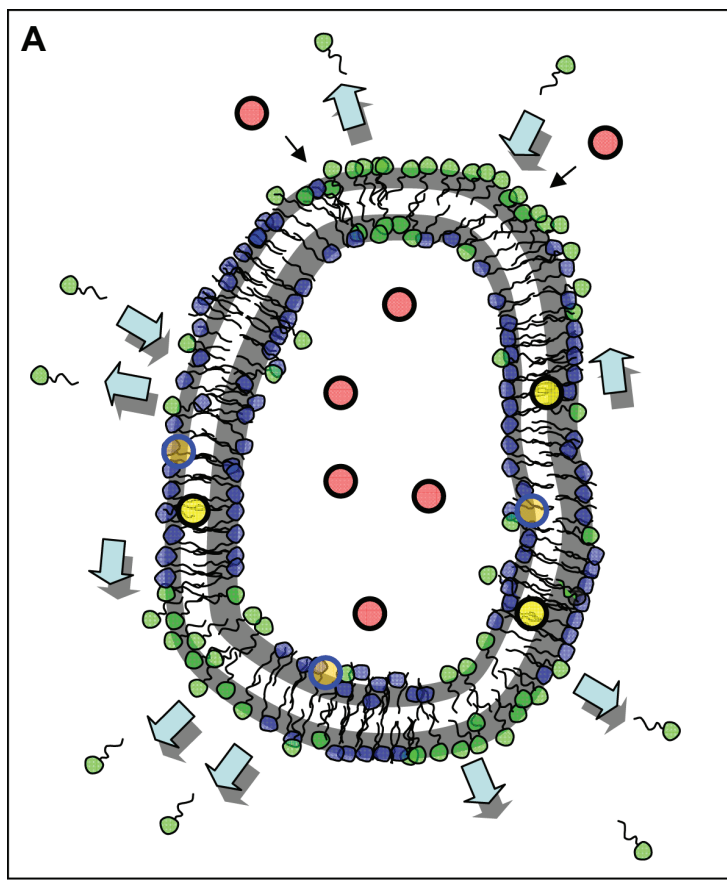

Hydrophilic solute no Edge activator
Hydrophobic solute

$\{3$

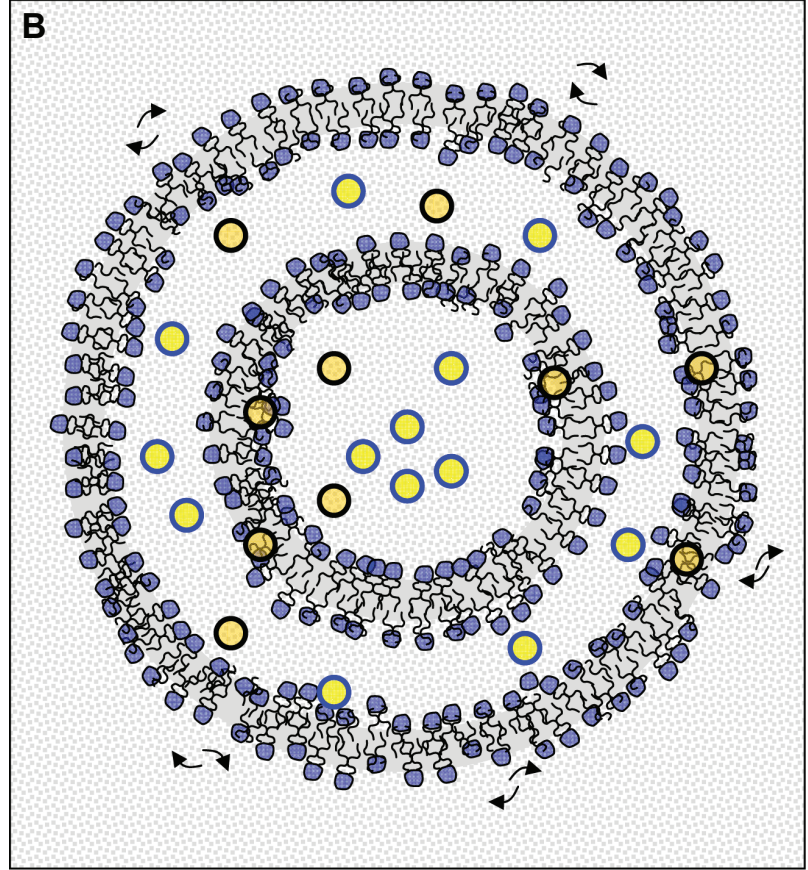

Amphipathic solute

\section{$20 \%-30 \%$ ethanol solution}

20 Edge activator 2 Pobility in mixing/partitioning/de-mixing of edge activator in bilayer $\triangle$ Partition of hydrophilic solutes Loose heads

Figure I A representative scheme of deformable vesicles (A), and fluid vesicles (ethosomes) (B). 
anisotropic, and the existence of bilayers in the $20 \%-45 \%$ ethanol range was confirmed. By the paramagnetic-ion NMR technique using $\mathrm{Pr}^{+3}$ as a shift reagent, the vesicularity and permeability of phospholipid dispersions in 30\%-45\% ethanol was revealed, showing that, between $20 \%$ and $30 \%$ ethanol, PC forms bilayers in the form of closed vesicles. Transmission electron microscopy of ethosomes composed of PC/ethanol (2\%/30\%) was shown to contain multilamellar vesicles, with lamellas extended to the core of the vesicles. ${ }^{32}$ As the ethanol content approaches $45 \%$, a small soluble fraction of phospholipids is mixed with the closed vesicles.

A unique property of ethosomes is the possibility of controlling their size as a function of the ethanol content, with no need for ad hoc equipment. For example, at $2 \%$ PC, the size of $\sim 200 \mathrm{~nm}$ diameter vesicles can be reduced to half as the ethanol concentration is increased from $20 \%$ to $45 \%$. Conversely, the ethosome size has a limited dependence on the $\mathrm{PC}$ concentration. An eightfold increase in PC concentration from $0.5 \%$ to $4 \%$ resulted in a two fold increase in ethosome size (120 nm to $250 \mathrm{~nm}$ ). Moreover, the high ethanol content is responsible for the negative $\mathrm{Z}$ potential in comparison to liposomes in the absence of ethanol. Due to the high negative $\mathrm{Z}$ potential, ethosomes has higher colloidal stability than its liposomal counterparts. Compared to liposomal bilayers, the phospholipids in ethosomes are packed less tightly and the membrane presents a higher permeability for hydrophilic/ ionic solutes. The ethosomes would not be well suited to entrap hydrophilic solutes. ${ }^{33}$ A key difference with TRS is that ethosomes can be successfully applied under occlusive conditions, which allows for the employing of patches. In spite of the high ethanol concentration, the average size and size distribution of ethosomes remains constant for at least 2 years at room temperature. ${ }^{34}$

After topical application, the permeation enhancement from ethosomes is much greater than would be expected from ethanol alone, suggesting a synergic mechanism between ethanol, vesicles, and skin lipids. Ethosomes are more effective permeation enhancers than ethanol, aqueous ethanol, or ethanolic phospholipid solutions. It is hypothesized that ethosomes might act as enhancers of drug permeation and as drug carriers through the SC. The ethanol may increase the solubility of the drug in the vesicle, disturb the organization of the SC lipid bilayer, and enhance its lipid fluidity. The subsequent mixing of phospholipids with SC lipids of the intercellular layers was observed to enhance the permeability of the skin. ${ }^{35}$ The rapid ethanol permeation across the skin, solvent 'drag', may carry drugs into the tissue as ethanol traverses. Finally, ethanol is a highly volatile constituent that might extract some of the lipid fraction from within the SC, with the consequence of improved drug flux through the skin when used at high concentrations for prolonged times. ${ }^{36}$ In other words, ethosomes would disrupt the lipophilic barrier of the skin. This barrier depends on the molecular weight and distribution coefficient rather than molecular size of permeants. The lipophilic barrier confines molecules heavier than 400-500 Da to the skin surface, but its height decreases with permeants' lipophilicity. ${ }^{19}$ Such mechanisms differ from that employed by TRS, which is neither mediated by fluidification nor fusion with the SC lipids. Penetration is the term used to describe the transport of vesicles as non-fragmented bilayers through a semipermeable barrier with pores smaller than the vesicular diameter under a driving force that can be hydrotactic, which vanishes after skin occlusion. ${ }^{37}$ This term is different from permeation; a term describing material transport across a barrier depending on a concentration gradient following Fick's law of diffusion, with the trans-barrier transport linearly correlated with the permeant's diffusivity and distribution coefficient, ${ }^{38}$ and the in vitro permeation broadly resembling the in vivo permeation. ${ }^{39}$ Lack of such proportionalities or correlations indicates a non-diffusive mechanism of transport. TRS are said to penetrate (and not to permeate) the SC by mechanisms dependent on structural adaptability but independent of any particular composition. Therefore, the mechanism mediating skin interaction is of key importance in deciding whether to include or not include the fluid vesicles developed in the last 10 years under the definition of TRS. ${ }^{12}$ Controversies over the classification of deformable or fluid vesicles arise when the mechanism of skin interaction is poorly defined. ${ }^{12,37}$

Hydrophilic solutes within deformable or fluid vesicles can experience difficulties in escaping across the barrier imposed by the lipid bilayers. Once released, the fate of hydrophilic solutes will depend on their affinity with epidermis/ dermis structures. For instance, deformable vesicles (soybean phosphatidylcholine [SPC]/sodium cholate at 8.8\%/1.2\% $\mathrm{w} / \mathrm{v}$ hydrated with $10 \% \mathrm{v} / \mathrm{v}$ ethanol) reduce the transdermal flux of the highly hydrophilic intermediate molecular weight drug model calcein in vivo, when compared to a solution containing or not containing sodium cholate and ethanol. The transdermal absorption of calcein from deformable vesicles is controlled by the release of the drug from the formulation deposited onto the skin surface. ${ }^{40}$ Besides, deformable vesicles (SPC/Tween 80 at 84.5/15.5 w/w hydrated with $7 \% \mathrm{v} / \mathrm{v}$ ethanol,) with the model hydrophilic drug ketotifen inside did not improve skin deposition and permeation over aqueous control in vitro. However, vesicles containing 
ketotifen outside significantly improved permeation and skin deposition after 24 hours of nonocclusive application over that of vesicles with ketotifen inside and with both ketotifen inside and outside. ${ }^{41}$ Similarly, ethosomes with ketotifen inside, and ethosomes with both ketotifen inside and outside, showed significant improvement in cumulative ketotifen permeation and skin deposition over ketotifen solution in 30\% ethanol. Ethosomes, however, were not able to improve skin delivery of non-entrapped ketotifen. ${ }^{41}$ On the contrary, the hydrophobic/amphipathic solutes penetrate exclusively associated to the vesicles. Remarkably, the entrapment efficiency (EE) for hydrophobic/amphipathic solutes of ethosomes is significantly high because of its solubilization on multilayers and hydroethanolic inner compartments. Liposomes lacking ethanol would only solubilize hydrophobic/amphipathic solutes within phospholipid bilayers. ${ }^{34}$

\section{Invasomes}

These are vesicles prepared from phospholipids, ethanol, and terpenes $(10 \% / 3.3 \% / 0.5 \%-1 \% \mathrm{w} / \mathrm{v})$, which serve as penetration enhancers. Similar to ethosomes, the permeation enhancing effect of invasomes has been explained by fluidizing and disturbing the organization of SC lipids. ${ }^{42,43}$ The increased fluidity of vesicles by the addition of terpenes and a disorganized SC bilayer structure are thought to facilitate the penetration of invasomes. However, no direct correlation between fluidity of invasomes and their penetration enhancing ability was found. Recently, the transdermal flux of vesicular formulations containing sodium cholate or Tween 80 was compared with that of invasomes. ${ }^{44}$ It was observed that the transdermal flux of TRS (with sodium cholate at $1 \%$ and $1.8 \% \mathrm{w} / \mathrm{w}$ ) was higher than those containing Tween 80 ( $\sim 60$ versus $\sim 40 \mathrm{mg} / \mathrm{s} \mathrm{cm}^{2}$ ). However, the highest values of $80 \mathrm{mg} / \mathrm{s} \mathrm{cm}^{2}$ were observed for $1 \%$ $\mathrm{w} / \mathrm{w}$ terpene mixture and $1 \%$ limonene-containing invasomes. Besides, the amount of calcein transported across the skin as calcein solution is minimal, but significantly higher amounts are transported when calcein is entrapped in conventional liposomes, TRS, or invasomes, with the order being: solution $<$ conventional liposomes $<$ TRS $<<$ invasomes. Although these differences are manifested beyond 10 hours of incubation, it is possible that penetration enhancers from invasomes will diffuse out of the vesicles and permeate the skin lipids to enhance drug transport.

\section{Penetration enhancer-containing vesicles (PEVs)}

These are vesicles prepared from phospholipids and penetration enhancers with hydrosoluble glycols such as diethylene glycol monoethyl ether (Transcutol ${ }^{\circledR}$, Gattefosse SA, Saint Priest, France) or propylene glycol (PG) at 10\%-30\% v/v. ${ }^{45}$ The permeation enhancer perturbs, in a dose-dependent manner, the phospholipid packing characteristics and, thus, fluidizes the vesicle bilayer. The deformability of PEVs is very close to that of conventional liposomes; thus, a similar mechanism of penetration to ethosomes has been proposed. The permeation enhancer has a dual effect; it improves vesicular bilayer fluidity and also reduces the SC barrier function transiently. ${ }^{46}$ Note that PEV is a rather confusing denomination, since ethosomes and invasomes are also penetration enhancer-containing vesicles.

\section{Preclinical applications as antitumorals}

Nonmelanoma skin cancer (NMSC) is the most common type of cancer in Caucasian populations. ${ }^{47,48}$ In the United States alone, 2 million people are diagnosed with nonmelanoma skin cancer every year, with squamous cell carcinoma (SCC) and basal cell carcinoma (BCC) accounting for the majority of cases. ${ }^{49}$ Surgical removal is the standard therapy for the treatment of SCC and BCC, but it may cause morbidity in high risk individuals and have negative cosmetic outcomes. Thus, the development of alternative modalities for the treatment of NMSC remains highly desirable. Topical treatment regimens are considered to be effective alternatives for NMSC. Skin delivery is noninvasive, achieves high local levels of drug (keratinocytes of the epidermis or its appendages and basal cells of epidermis where SCC and the BCC locate, respectively), minimizes systemic exposure, and is more acceptable to patients. ${ }^{50}$ We will discuss the few studies published to date. In most of them, penetration in vitro and/or in vivo and cytotoxicity were studied (Table 1).

\section{Chemotherapy}

The first preclinical studies on skin chemotherapy mediated by deformable vesicles are relatively recent (2005) and determine the cytotoxicity of the hydrophilic bleomycin in Transfersomes ${ }^{51}$ as well its in vivo skin penetration. ${ }^{52}$

A few later ethosomes and microneedles were employed for the topical delivery of the hydrophobic antitumoral agent docetaxel (DTX) ${ }^{53}$ DTX is used in the treatment of breast, ovarian, and non-small-cell lung cancers. It is a semisynthetic analog of paclitaxel (MW: 807.9), lipophilic $(\log \mathrm{P}=4.1)$ and poorly water soluble $(6-7 \mu \mathrm{g} / \mathrm{mL})$, with limited transdermal permeation. It was found that DTX-ethosomes enhanced transdermal delivery of DTX across both rat and porcine skin without microneedle treatment, superior under occlusive 
Table I Antitumoral agents

\begin{tabular}{|c|c|c|c|c|}
\hline $\begin{array}{l}\text { Vesicle } \\
\text { type/drug }\end{array}$ & $\begin{array}{l}\text { Composition and } \\
\text { structural properties }\end{array}$ & Studies & Results & Reference \\
\hline $\begin{array}{l}\text { TRS } \\
\text { Bleomycin }\end{array}$ & $\begin{array}{l}\mathrm{EPC} / \mathrm{NaChol}(10 \% \mathrm{w} / \mathrm{w}) \\
\mathrm{I} 50-200 \mathrm{~nm} .\end{array}$ & $\begin{array}{l}\text { Cytotoxicity on immortalized human } \\
\text { cutaneous keratinocytes (NEB-I) } \\
\text { and human squamous carcinoma } \\
\text { cells (SCC). }\end{array}$ & $\begin{array}{l}\text { LD50 of bleomycin-TRS was } \sim 3 \text {-fold higher than } \\
\text { that of free bleomycin for SCC cells and } \sim 30 \text { times } \\
\text { higher for NEB-I cells. Bleomycin-TRS at } 30 \mu \mathrm{g} / \mathrm{mL} \\
\text { killed more than double SCC cells compared to } \\
\text { NEB-I cells and was similar to that of bleomycin } \\
\text { solution. }\end{array}$ & 51 \\
\hline $\begin{array}{l}\text { TRS } \\
\text { Bleomycin }\end{array}$ & $\begin{array}{l}\mathrm{SPC} / \mathrm{NaChol}(16 \% \mathrm{w} / \mathrm{w}) \\
\text { with beta-sitosterol 3- } \beta-\mathrm{D}- \\
\text { glucoside (SitG) }(5 \% \mathrm{w} / \mathrm{w}) \\
\mathrm{I} 14-53 \mathrm{~nm},-30 \mathrm{mV}, \\
28 \% \mathrm{EE} .\end{array}$ & In vivo permeation through rat skin. & $\begin{array}{l}\text { Permeation of } \mathrm{NaChol-TRS,} \mathrm{NaChol} / \mathrm{SitG}-\mathrm{TRS} \text { and } \\
\text { conventional liposomes was } 4,6 \text { and I\% dose, } \\
\text { respectively. } \mathrm{NaChol-TRS} \text { and } \mathrm{NaChol} / \mathrm{SitG}-\mathrm{TRS} \\
\text { showed absorption of bleomycin into epidermis } \\
\text { and dermis. } \mathrm{NaChol} / \mathrm{SitG}-\mathrm{TRS} \text { delivered higher skin } \\
\text { concentrations of drug than } \mathrm{NaChol-TRS} \text {. }\end{array}$ & 52 \\
\hline $\begin{array}{l}\text { Ethosomes } \\
\text { DTX }\end{array}$ & $\begin{array}{l}\text { DTX/SPC/NaChol/EtOH/ } \\
\text { PBS }(0.14 / 6 / 1 \mathrm{I} / \mathrm{I} / 65 \% \mathrm{w} / \mathrm{w}) \\
\text { Sonicated }(43 \mathrm{~nm}) \text { and } \\
\text { not sonicated }(200 \mathrm{~nm}) \\
80 \%-88 \% \text { EE. }\end{array}$ & $\begin{array}{l}\text { In vitro permeation through rat } \\
\text { and pig skin under occlusive and } \\
\text { nonocclusive application of } 100 \mu \mathrm{L} \\
\text { on } 0.636 \mathrm{~cm}^{2} \text {. }\end{array}$ & $\begin{array}{l}\text { On rat skin, under both conditions cumulatively } \\
\text { larger amounts and steady-state flux for DTX- } \\
\text { ethosomes compared to conventional liposomes } \\
\text { were shown. On porcine skin, under nonocclusive } \\
\text { application, DTX concentration was below the } \\
\text { limit of determination. Under occlusive application, } \\
\text { DTX-ethosomes improved skin delivery compared } \\
\text { to conventional liposomes and } 20 \% \text { w/w ethanolic } \\
\text { solution. }\end{array}$ & 53 \\
\hline $\begin{array}{l}\text { Ethosomes } \\
\text { PTX }\end{array}$ & $\begin{array}{l}\mathrm{PC} / \mathrm{EtOH}(\mathrm{I} \% / 45 \% \mathrm{w} / \mathrm{v}) \\
240 \pm 6 \mathrm{I} \mathrm{nm}, \sim 57 \% \mathrm{EE} .\end{array}$ & $\begin{array}{l}\text { In vitro permeation through human } \\
\mathrm{SC} \text { and viable epidermis under } \\
\text { nonocclusive application. } \\
\text { Cytotoxicity on DJM-I cells. }\end{array}$ & $\begin{array}{l}\text { Flux of PTX-ethosomes was } 3.2 \text { - and } 23.2- \\
\text { fold higher than PTX in physical mixture and } \\
\text { PTX-hydroethanolic suspension, respectively. } \\
\text { PTX-ethosomes elicited the greatest dermal } \\
\text { accumulation. At } 5 \mu \mathrm{M} \text {, PTX and PTX-ethosomes } \\
\text { caused } 40 \% \text { and } 90 \% \text { cell death after } 72 \text { hours, } \\
\text { respectively. }\end{array}$ & 54 \\
\hline $\begin{array}{l}\text { Ethosomes } \\
\text { ALA }\end{array}$ & $\begin{array}{l}\mathrm{PE} \text { and } \mathrm{PE} / \mathrm{Chol} / \mathrm{SS} ;(2: \mathrm{I}: 2.5 \\
\text { molar ratio) with I5\% EtOH, } \\
<200 \mathrm{~nm},-70 \mathrm{mV}, \mathrm{PE} / \mathrm{Chol} / \\
\mathrm{SS} 66 \% \mathrm{EE}, \mathrm{PE} \mathrm{I} \% \% \mathrm{EE} .\end{array}$ & $\begin{array}{l}\text { In vivo permeation by CLSM. } 100 \mu \mathrm{L} \\
\text { was applied on } 0.785 \mathrm{~cm}^{2} \text { of the } \\
\text { dorsal skin of nude mice. Irradiated } \\
\text { at } 120 \mathrm{~J} / \mathrm{cm}^{2} \text {. }\end{array}$ & $\begin{array}{l}\text { Penetration depth of ethosomes was higher than } \\
\text { that of liposomes. }\end{array}$ & 58 \\
\hline $\begin{array}{l}\text { Invasomes } \\
\text { mTHPC }\end{array}$ & $\begin{array}{l}\mathrm{SPC} / \mathrm{EtOH} / \text { terpenes } \\
\text { (cineole, citral, and } \\
\text { D-limonene at } 45: 45: 10, \mathrm{v} / \mathrm{v} \text { ) } \\
(10 \% / 3.3 \% / 0.5 \%-1 \% \mathrm{w} / \mathrm{v}) \\
150 \mathrm{~nm},-13 \mathrm{mV} \text {. }\end{array}$ & $\begin{array}{l}\text { In vitro permeation through } \\
\text { abdominal human skin under } \\
\text { nonocclusive application, } 10 \mu \mathrm{L} / \mathrm{cm}^{2} \\
\text { was applied on } 3.14 \mathrm{~cm}^{2} \text {. }\end{array}$ & $\begin{array}{l}\text { SC deposition and skin depth profile of mTHPC } \\
\text { decreased in the following order: invasomes I\% } \\
\text { terpenes }>\text { invasomes } 0.5 \% \text { terpenes }>\text { ethanolic } \\
\text { solution }>\text { liposomes } 3.3 \% \text { ethanol }>\text { conventional } \\
\text { liposomes. mTHPC-invasomes with I\% terpenes } \\
\text { penetrated into viable epidermis and dermis. }\end{array}$ & 66 \\
\hline $\begin{array}{l}\text { Invasomes } \\
\text { mTHPC }\end{array}$ & $\begin{array}{l}\text { SPC/EtOH/terpenes or } \\
\text { citral }(10 \% / 3.3 \% / 1 \% \mathrm{w} / \mathrm{v}) \text {. }\end{array}$ & $\begin{array}{l}\text { I0 } \mathrm{LL} / \mathrm{cm}^{2} \text { was applied onto } 3 \mathrm{~cm}^{2} \\
\text { of mouse skin nonocclusively } 10 \text { days } \\
\text { after subcutaneous implanted HT29 } \\
\text { cells. Irradiated at } 20 \mathrm{~J} / \mathrm{cm}^{2} \text { on II th } \\
\text { and I9th day after tumor induction. }\end{array}$ & $\begin{array}{l}\text { Only invasomes with } 1 \% \text { of terpenes led to } \\
\text { a significantly slower increase in tumor size } \\
\text { compared to mice without any treatment } \\
\text { and mice treated with photoirradiation. }\end{array}$ & 67 \\
\hline $\begin{array}{l}\text { Invasomes } \\
\text { mTHPC }\end{array}$ & $\begin{array}{l}\text { SPC/EtOH/terpenes or } \\
\text { citral }(10 \% / 3.3 \% / 1 \% \mathrm{w} / \mathrm{v}) \text {. } \\
120-140 \mathrm{~nm} \text {. }\end{array}$ & $\begin{array}{l}\text { Cytotoxicity on human epidermoid } \\
\text { carcinoma cell line A43I and HT29 } \\
\text { photoirradiation at } 20 \mathrm{~J} / \mathrm{cm}^{2} \text {. }\end{array}$ & $\begin{array}{l}\text { mTHPC-invasomes and mTHPC-ethanolic solution } \\
\text { reduce survival of HT29 cells and, especially, } \\
\text { A43I cells, being more sensitive to PDT. }\end{array}$ & 69 \\
\hline $\begin{array}{l}\text { TRS } \\
\text { mTHPC }\end{array}$ & $\begin{array}{l}\text { SPC:Tween } 20 \text { (84.6: } \\
\text { I5.4 w/w); SPC:SA:Tween } \\
20 \text { (8I:3.25: I } 5 \mathrm{w} / \mathrm{w}) \\
\text { SPC: dicetyl phosphate: } \\
\text { Tween } 20(78: 6: 15 \mathrm{w} / \mathrm{w}) \\
95 \mathrm{~nm},-5.5 ;+39 \\
\text { and }-39 \mathrm{mV} \text {, respectively. }\end{array}$ & $\begin{array}{l}\text { In vitro skin permeation through } \\
\text { human abdominal skin under } \\
\text { nonocclusive application of } \\
10 \mu \mathrm{L} / \mathrm{cm}^{2} \text { on } 3.14 \mathrm{~cm}^{2} \text {. }\end{array}$ & $\begin{array}{l}\text { SC deposition of mTHPC decreased in the } \\
\text { following order: cationic }>\text { neutral }>\text { anionic TRS }> \\
\text { conventional liposomes. Cationic TRS provided the } \\
\text { highest accumulation of mTHPC in the deeper skin } \\
\text { layers, followed by neutral and anionic TRS. mTHPC } \\
\text { was not found in the acceptor compartment } \\
\text { regardless of the applied vesicle formulation, } \\
\text { indicating no risk of systemic side-effects. }\end{array}$ & 70 \\
\hline
\end{tabular}

Notes: Structural properties included size $(\mathrm{nm}), \mathrm{Z}$ potential $(\mathrm{mV})$, and entrapment efficiency $(\% \mathrm{EE})$.

Abbreviations: ALA, 5-aminolevulinic acid; Chol, cholesterol; EE, entrapment efficiency; EPC, egg phosphatidylcholine; EtOH, ethanol; mTHPC, temoporfin; NaChol, sodium cholate; PBS, phosphate buffered saline; PE, phosphatidylethanolamine; SA, Stearylamine; SitG, Beta-sitosterol 3- $\beta$-D-glucoside; SC, stratum corneum; SPC, soya phosphatidylcholine; SS, sodium stearate; LD50, lethal dose 50\%; DTX, docetaxel; PC, phosphatidylcholine; PTX, paclitaxel; DJM-I, human squamous-cell-carcinoma cell line; HT29, human colon adenocarcinoma grade II cell line; CLSM, confocal laser scanning microscopy; Z, zeta; TRS, Transfersomes ${ }^{\circledR}$ (IDEA AG, Munich, Germany). 
conditions. An enhanced transdermal flux for DTX on porcine skin from liposomal formulations was observed if combined with a previous microneedle treatment as well as a minimal lag time for DTX-ethosomes through microneedle-treated skin. However, this work focuses on the transdermal delivery of an antitumoral drug that would act on non-skin targets. The advantages of diminishing the systemic side effects and increasing the local activity are unclear.

More recently, the topical delivery of another hydrophobic antitumoral agent in ethosomes was tested. ${ }^{54}$ Paclitaxel (PTX) is a highly hydrophobic macrocyclic, that can accumulate within the SC and does not penetrate into the deeper skin layers. ${ }^{55,56}$ Currently, PTX is intravenously administered as Taxol $^{\circledR}$ (Bristol-Myers Squibb Company, Princeton, NJ, USA), in a Cremophor EL ${ }^{\circledR}$ (BASF SE, Limburgerhof, Germany) and ethanol (50\%:50\% v/v) formulation, or Abraxane ${ }^{\circledR}$ (Celgene Corporation, Summit, NJ, USA) in an albumin nanoparticle formulation. In agreement with that observed for other hydrophobic compounds, ${ }^{34}$ PTX was homogeneously distributed in the hydroethanolic and hydrophobic compartments of the ethosomes. The EE was higher as the percentage of ethanol increased, without promoting a compartmentalization of the drug as observed in liposomes. ${ }^{57}$ PTX-ethosomes permeated faster through human SC and viable epidermis than free PTX or PTX/empty-ethosomes physical mixture. PTX-ethosomes provided a sustained release of PTX suitable for in vivo administration. The antiproliferative effect on DJM-1 cells (a human skin SCC cell line that represents the malignant progression and differentiation of actinic keratosis [AK] after exposition to ultraviolet [UV] radiations) was higher for PTXethosomes as compared with the remaining formulations.

\section{Photodynamic therapy (PDT) with 5-aminolevulinic acid (ALA)}

The penetration depth and skin production of protoporphyrin IX by different formulations of ALA in liposomes and in ethosomes on irradiated nude mice was reported. ${ }^{58}$ ALA is a precursor of the photosensitizer protoporphyrin IX (PpIX), formed in vivo after the exogenous application of ALA. ${ }^{59}$ In PDT, PpIX activated by a suitable wavelength generates singlet oxygen, by a cascade of reactions. The cytotoxic effect of singlet oxygen on tumors occurs by two pathways: destruction of tumor cells by necrosis or apoptosis and the failure of tumor vascularization by a decline in oxygen-carrying blood. ${ }^{60,61}$ ALA molecules are hydrophilic zwitterions; thus, the major limitation of ALA mediated topical PDT is the poor penetration of ALA through cell membranes or the skin. ${ }^{62}$ In general, liposomes and ethosomes display low entrapment efficiencies of ALA because of its hydrophilicity. ${ }^{63}$ Moreover, the entrapment of hydrophilic molecules in ethosomes is less efficient than that of hydrophobic molecules. ${ }^{33}$ This work showed that, in vivo, the fluorescence intensity of PpIX was maximal after topical application of ALA in phosphatidylethanolamine (PE) ethosomes (minimal EE with 90\% external ALA versus maximal EE for PE:cholesterol (Chol):sodium stearate (SS) ethosomes) as compared to that achieved by ALA in aqueous solution, ethanolic solution, and liposomes. In accordance with previously reported experimental evidence, ${ }^{64}$ a correlation between EE and PpIX delivery to an epidermal target was absent. According to the authors, the ethosomes would act as permeation enhancers for the free hydrophilic solute, increasing the opportunities for free ALA to be taken up by epidermal cells. However, this explanation contradicts the hypothesis made by Elsayed et al on the absence of permeation enhancement by ethosomes on free hydrophilic solutes. ${ }^{41}$ The PE:Chol:SS ethosomes of higher EE, on the other hand, would not allow the release of ALA from the inner side of ethosomes. In other words, liposomal phospholipids form an extra lipid barrier from where the hydrophilic drug is slowly released. Because of this, in spite of gaining access to deep skin layers, ALA in PE:Chol:SS ethosomes would not be available to be metabolized to PpIX. ${ }^{65}$ This work, however, did not assess cytotoxicity on keratinocytes and lacks a suitable comparison with TRS.

\section{PDT with temoporfin}

Temoporfin (mTHPC) is a highly hydrophobic secondgeneration photosensitizer with low percutaneous penetration. mTHPC has shown to be effective in the PDT of early or recurrent oral carcinomas, in the palliative treatment of refractory oral carcinomas, and in the treatment of primary NMSC of the head and neck. Until now, for all positive findings, intravenous application of mTHPC was mandatory.

A former study compared the in vitro skin penetration of mTHPC-invasomes with that of liposomes, liposomes containing ethanol, and ethanolic solution. ${ }^{66}$ It was found that mTHPC-invasomes with $1 \%(\mathrm{w} / \mathrm{v})$ terpene mixture significantly enhanced deposition of MTHPC in the SC and into the deeper layers of the skin. It was also found that topical skin application of mTHPC-invasomes followed by photoirradiation slowed down tumor growth in mice bearing a subcutaneously implanted human colorectal tumor HT29, compared with no treatment. ${ }^{67}$ The subcutaneous localization and the intermediate sensitivity against PDT of the tumor HT29 were claimed to limit the success of the therapy. However, this would 
not be a suitable model of NMSC; the anticancer efficacy of topical treatments can be tested in mice bearing A431 (human epidermoid carcinoma cell line) intradermal xenografts. ${ }^{50}$

Invasomes containing $1 \%(\mathrm{w} / \mathrm{v})$ cineole provided the largest enhancement of skin penetration of mTHPC, followed by invasomes containing $1 \%(\mathrm{w} / \mathrm{v})$ of the standard terpene mixture. ${ }^{68}$ The in vitro PDT efficacy of mTHPC-invasomes was higher against human epidermoid carcinoma cells (A431) (16\% survival after 24 hours) than on HT29 cells. ${ }^{69}$

Finally, mTHPC-loaded in cationic TRS showed the highest penetration enhancing ability compared to conventional liposomes, neutral, and anionic TRS. The positive charges on the surface of cationic liposomes could bind to negative charges of the SC, leading to an enhanced drug penetration into/through the skin. ${ }^{70}$ Regarding the penetration enhancing effect, TRS showed comparable ability to invasomes containing $0.5 \%(\mathrm{w} / \mathrm{w})$ terpenes, but they were less efficient than invasomes containing $1 \%(\mathrm{w} / \mathrm{w})$ terpenes. However, this work did not assess cytotoxicity on keratinocytes.

\section{Preclinical applications as anti-inflammatory agents}

Between 1997 and 2004, Cevc et al performed a series of preclinical studies on mice to assess the performance of topical glucocorticoids in TRS. ${ }^{71-73}$ To increase diffusion and local activity, conventional lotions, ointments or gels for topical delivery contain high concentration (at supersaturation) of glucocorticoids plus a high content of permeation-enhancers. These conditions lead to drug metastability, ${ }^{74}$ decreased permeability of the barrier, ${ }^{75}$ and unnecessary systemic delivery. Briefly, the rationale for improving the topical delivery of glucocorticoids is based on the capacity of TRS to cross the intact SC following the hydration gradient. ${ }^{76}$ The penetration of TRS would cease after entering the viable epidermis and a sub-SC deposit is formed. ${ }^{14,16,21}$ Since this penetration is independent of diffusion, the existence of a concentration gradient of active ingredient is no longer relevant. In other words, TRS enables the active penetration of low doses of active ingredient across the intact SC. These remarkable initial findings highlighted the possibility of increasing the time of action, potency, regioselectivity, and safety of topical hydrocortisone, dexamethasone, or triamcinolone acetonide. ${ }^{71}$ Overall, it was found that a low dose-per-area favors the drug retention in the skin, while an increased total applied drug dose, and increased dose-per-area promoted the systemic drug availability. At low dose-per-area, the skin toxicity was reduced and sub-SC deposits of corticoids were formed in the epidermis; in the absence of permeation enhancers and minimizing the systemic spill-over. The fate and the activity of the carrier-transported corticosteroids in the skin are dependent on the agent solubility in the tissue. It was observed that hydrophilic drugs such as hydrocortisone could leave the TRS and diffuse into the surrounding hydrophilic environment, whereas liposoluble triamcinolone acetonide remained associated with TRS bilayers favoring the formation of an epidermal deposit. ${ }^{72}$ In humans, similar results were achieved with triamcinolone acetonide in TRS. ${ }^{77}$ By the accumulation of sub-SC deposits at low doses-perarea, the TRS proved to increase the performance of low biological potency drugs such as the short acting hydrocortisone and the long acting dexamethasone. ${ }^{73}$

Topical glucocorticoids are associated with thinning of the epidermis and dermis, decreasing subcutaneous adipose tissue, and suppressing epidermal cell proliferation leading to a potential discontinuation of the therapy when repeatedly used; a fact that could result in sudden aggravation of symptoms. ${ }^{78}$ Due to these reasons, the quest to develop drugs with fewer safety problems is urgent. Initial preclinical studies employing ethosomes ${ }^{79,80}$ and $\mathrm{TRS}^{81}$ as carriers for topical NSAIDs are shown in Table 2.

The first preclinical study assessing the performance of NSAIDs in TRS was launched in 2001 by Cevc and Blume. ${ }^{38,39,82}$ TRS enabled the route of administration to be modified, reduce the therapeutic dose, and achieve region selective delivery of NSAIDs to deep subcutaneous tissue. We will briefly describe the most relevant results on diclofenac and ketoprofen in TRS (Transfenac ${ }^{\circledR}$ [IDEA AG, Muenchen, Germany] and Diractin ${ }^{\circledR}$ [IDEA AG, Muenchen, Germany], respectively).

Diclofenac (sodium salt) is a poorly hydrosoluble (2.37 mg/L, $\log \mathrm{P} 4.51)$, acetic acid-derived NSAID, with analgesic and antipyretic properties. It inhibits both leukocyte migration and the enzyme cyclooxygenase (COX-1 and COX-2; an enzyme involved in prostaglandin synthesis via the arachidonic acid pathway). Antipyretic effects may be due to action on the hypothalamus. In spite of its potency and high oral bioavailability, its low specificity is associated with adverse effects, primarily in the gastrointestinal tract. Orally administered diclofenac is poorly tolerated and causes stomach ulcerations. ${ }^{78,83}$ The therapeutic diclofenac concentration in target tissues is approximately $0.5 \mu \mathrm{g} / \mathrm{g}$ tissue, a concentration that should be achieved while simultaneously keeping its systemic and gastrointestinal concentrations as low as possible. Most NSAID molecules diffuse across the $\mathrm{SC}$ and into deeper skin regions rather 
Table 2 Anti-inflammatory, anti-scarring, anti-atopic dermatitis and anti-psoriasis agents

\begin{tabular}{|c|c|c|c|c|}
\hline $\begin{array}{l}\text { Vesicle } \\
\text { type/drug }\end{array}$ & $\begin{array}{l}\text { Composition and } \\
\text { structural properties }\end{array}$ & Studies & Results & Reference \\
\hline $\begin{array}{l}\text { Ethosomes } \\
\text { CBD }\end{array}$ & $\begin{array}{l}\mathrm{CBD} / \mathrm{EtOH} 3 \% / 40 \% \mathrm{w} / \mathrm{w} \text {. } \\
\mathrm{CBD} / \mathrm{SPC}(1: 2 \text { molar } \\
\text { ratio) in carbomer gel. } \\
300-400 \mathrm{~nm} \text {. }\end{array}$ & $\begin{array}{l}\text { CBD skin permeation and } \\
\text { organ distribution was measured } \\
\text { in CDI nude mice. Anti- } \\
\text { inflammatory effect on } \\
\text { carrageenan-induced aseptic } \\
\text { paw edema in male ICR mice. }\end{array}$ & $\begin{array}{l}\text { Accumulation of CBD in the skin and in the } \\
\text { underlying muscle. Steady-state levels were } \\
\text { reached at } \sim 24 \text { hours and lasted at least until } \\
72 \text { hours. Application of ethosomes on } \\
\text { abdominal area prevented the inflammation } \\
\text { and edema of the right hind paw. }\end{array}$ & 79 \\
\hline $\begin{array}{l}\text { Ethosomes } \\
\text { ammonium } \\
\text { glycyrrhizinate }\end{array}$ & $\begin{array}{l}\text { SPC/EtOH } 2 \%(w / v) . \\
45 \%(v / v) .100 \mathrm{~nm} .\end{array}$ & $\begin{array}{l}\text { In vitro permeation through } \\
\text { human SC and epidermis } \\
\text { membranes. Toxicity, drug } \\
\text { permeation, and anti- } \\
\text { inflammatory activity in a } \\
\text { model of skin erythema on } \\
\text { human volunteers were } \\
\text { evaluated. }\end{array}$ & $\begin{array}{l}\text { Very good skin tolerability. Ethosomes increase } \\
\text { permeation of ammonium glycyrrhizinate, and } \\
\text { enhance the anti-inflammatory activity compared } \\
\text { to the ethanolic or aqueous solutions of ammonium } \\
\text { glycyrrhizinate. }\end{array}$ & 80 \\
\hline $\begin{array}{l}\text { TRS } \\
\text { SOD }\end{array}$ & $\begin{array}{l}\text { SPC: NaChol ( } 3.75: \\
\text { I molar ratio) } \\
\text { SOD was added to the } \\
\text { vesicles, } 150 \pm 50 \mathrm{~nm} .\end{array}$ & $\begin{array}{l}\text { Epicutaneous administration on } \\
\text { day I onwards post-induction of } \\
\text { adjuvant arthritis. Prophylactically } \\
\text { SOD-TRS was epicutaneous } \\
\text { administered } 3 \text { days before } \\
\text { arthritis induction. }\end{array}$ & $\begin{array}{l}\text { Two SOD-TRS doses produced } 53 \% \text { of edema } \\
\text { regression and an increase of the total thiol } \\
\text { concentration in animal sera. Radiographic images } \\
\text { showed good preservation of the joint space and } \\
\text { soft tissues around the joint. Prophylactically, } \\
\text { SOD-TRS was able to suppress the induced rat } \\
\text { paw edema. }\end{array}$ & 81 \\
\hline $\begin{array}{l}\text { PEVs acid and } \\
\text { sodium salt } \\
\text { diclofenac }\end{array}$ & $\begin{array}{l}\text { SPC }(90 \mathrm{mg}) / \text { Oleic acid } \\
(10 \mathrm{mg}) / \text { Transcutol } \\
(10 \%, 20 \%, 30 \% \mathrm{v} / \mathrm{v}) \\
87-146 \mathrm{~nm},-53 \\
\text { to }-78 \mathrm{mV} \text {. Acid } \\
\text { diclofenac (65\%-75\% } \\
\text { EE), Na diclofenac } \\
(50 \%-57 \% \text { EE). }\end{array}$ & $\begin{array}{l}\text { In vitro permeation through new } \\
\text { born pig skin under nonocclusive } \\
\text { application. } 100 \mu \mathrm{L} \text { was applied } \\
\text { on } 0.785 \mathrm{~cm}^{2} .\end{array}$ & $\begin{array}{l}\text { Only acid diclofenac-PEVs showed 3-fold more } \\
\text { elasticity than conventional liposomes. Accumulation } \\
\text { into the skin of acid diclofenac was greater than or } \\
\text { equal to the sodium salt. For acid diclofenac, the } \\
\text { highest drug accumulation was found in the } \\
\text { epidermis, } 10 \%-20 \% \text { Transcutol enhanced drug } \\
\text { deposition three times more than conventional } \\
\text { liposomes. Transdermal delivery was higher for } \\
\text { the sodium salt form. }\end{array}$ & 45 \\
\hline $\begin{array}{l}\text { Ethosomes } \\
\text { PEVs diclofenac } \\
\text { sodium salt }\end{array}$ & $\begin{array}{l}\mathrm{PC} / \mathrm{EtOH}(90 \mathrm{mg} / 0.2 \\
\mathrm{mL}) ; \mathrm{PC} / \text { Transcutol } \\
(9 / \mathrm{I} \mathrm{w/w}) ; \mathrm{PC} / \mathrm{PG} \\
(9 / \mathrm{l} / \mathrm{w}) 100 \mathrm{~nm}, \\
\text { negatively charged, } \\
52 \%-65 \% \mathrm{EE} .\end{array}$ & $\begin{array}{l}\text { In vitro permeation through } \\
\text { mice skin under nonocclusive } \\
\text { application, } 100 \mu \mathrm{L} \text { was applied } \\
\text { on } 0.785 \mathrm{~cm}^{2} \text {. Anti-inflammatory } \\
\text { efficacy: topically applied over } \\
\text { the same dorsal site } 3 \text { hours } \\
\text { after phorbol ester treatment } \\
\text { (TPA). Procedure was repeated } \\
\text { on day } 2 \text { and } 3 .\end{array}$ & $\begin{array}{l}\text { Accumulation of diclofenac into the skin by } \\
\text { Transcutol-PEVs was 3.0- and I.6-fold higher } \\
\text { than aqueous solution and Voltaren, respectively, } \\
\text { and by ethosomes and PG-PEVs was two-fold } \\
\text { higher than solution and comparable to Voltaren. } \\
\text { All vesicles reduce diclofenac permeation and flux } \\
\text { in comparison with solution and Voltaren. Edema } \\
\text { was reduced more efficiently by diclofenac-vesicles, } \\
\text { and was practically abolished by diclofenac-PG-PEVs. } \\
\text { Diclofenac-vesicles caused I.9-2.7-fold decrease in } \\
\text { myeloperoxidase activity compared to non-treated } \\
\text { animals and Voltaren treated animals. }\end{array}$ & 90 \\
\hline $\begin{array}{l}\text { Ethosomes } \\
\text { ketoprofen }\end{array}$ & $\begin{array}{l}\mathrm{SPC} / \mathrm{EtOH}(1 \%-3 \% \text { and } \\
20 \%-40 \%) \text { I } 20-420 \mathrm{~nm} \text {, } \\
45 \%-78 \% \mathrm{EE} \text {. }\end{array}$ & $\begin{array}{l}\text { In vitro permeation through } \\
\text { human skin. }\end{array}$ & $\begin{array}{l}\text { Ketoprofen-ethosomes improved drug permeation } \\
\text { and showed higher transdermal flux compared } \\
\text { to hydroethanolic drug solution. }\end{array}$ & 93 \\
\hline $\begin{array}{l}\text { Ethosomes } \\
5-\mathrm{FU}\end{array}$ & $\begin{array}{l}\mathrm{SPC} / 5-\mathrm{FU} / \mathrm{EtOH} \text { and } \\
\mathrm{PBS}([2 \% \mathrm{w} / \mathrm{v}] / \\
{[0.4 \% \mathrm{w} / \mathrm{v}] /[30 \% \mathrm{v} / \mathrm{v}] /} \\
[68 \% \mathrm{v} / \mathrm{v}]), 65 \mathrm{~nm} \text {. }\end{array}$ & $\begin{array}{l}\text { In vitro permeation through } \\
\text { human } \mathrm{HS} \text { and skin, } 250 \mu \mathrm{L} \\
\text { on } 2.8 \mathrm{~cm}^{2} \text { under nonocclusive } \\
\text { application. }\end{array}$ & $\begin{array}{l}\text { Total amounts of 5-FU that permeated skin were: } \\
\text { ethosomes-scar }>\text { hydroethanolic solution- scar }> \\
\text { ethosomes-skin }>\text { Hydroethanolic solution-skin. }\end{array}$ & 32 \\
\hline $\begin{array}{l}\text { Ethosomes } \\
\text { ALA }\end{array}$ & $\begin{array}{l}\text { PE }(0.13 \mathrm{mM}) \text { with } \\
0.1 \% \text { ALA dissolved in } \\
15 \% \text { v/v EtOH solution. }\end{array}$ & $\begin{array}{l}\text { Permeation and recovery of skin } \\
\text { in a hyperproliferative murine } \\
\text { model, } 100 \mu \mathrm{L} \text { was applied on } \\
0.785 \mathrm{~cm}^{2} \text { of the dorsal skin } \\
\text { of mice. }\end{array}$ & $\begin{array}{l}\text { ALA-ethosomes increased cumulative amounts } \\
\text { five- to } 26 \text {-fold in normal and hyperproliferative } \\
\text { murine skin samples compared to ALA aqueous } \\
\text { solution. ALA-ethosomes increased four-fold PpIX } \\
\text { intensity compared to solution. Penetration depth } \\
\text { reached } 20-50 \mu \mathrm{m} \text {. }\end{array}$ & 106 \\
\hline
\end{tabular}


Table 2 (Continued)

\begin{tabular}{|c|c|c|c|c|}
\hline $\begin{array}{l}\text { Vesicle } \\
\text { type/drug }\end{array}$ & $\begin{array}{l}\text { Composition and } \\
\text { structural properties }\end{array}$ & Studies & Results & Reference \\
\hline $\begin{array}{l}\text { TRS } \\
\text { TXG }\end{array}$ & $\begin{array}{l}\text { PC/Tween 80/MPB-PE } \\
\text { (89: I0:0.5) bound to } \\
\text { Pep-I peptide. } 130 \mathrm{~nm} \text {, } \\
25 \mathrm{mV} \text {. }\end{array}$ & $\begin{array}{l}\text { In vitro permeation through } \\
\text { depilated mouse skin. } \\
\text { Atopic dermatitis-like lesions } \\
\text { were induced by repeat } \\
\text { application of 2,4,6-trinitro- I- } \\
\text { chloro-benzene on NC/Nga } \\
\text { mice. Mice were treated daily } \\
\text { for } 3 \text { weeks. }\end{array}$ & $\begin{array}{l}\text { TXG-PepI-TRS increased 3.5- and 9.4-fold the } \\
\text { amount of TXG permeated compared to TXG- } \\
\text { Tr and TXG solution, respectively. Mice treated } \\
\text { with TXG-solution and TXG-PepI-TRS showed } \\
\text { reduced TEWL within a week. TXG-PepI-TRS } \\
\text { treated group showed equivalent TEWL values } \\
\text { as the normal group after } 3 \text { weeks treatment. TXG } \\
\text { solution and TXG-PepI-TRS led to reduction in serum } \\
\text { IL-4 and IgE levels, and a ten-fold increase of IFN- } \gamma \text {. }\end{array}$ & 115 \\
\hline $\begin{array}{l}\text { Ethosomes } \\
\text { tacrolimus }\end{array}$ & $\begin{array}{l}\text { SPC/EtOH/PG }(2 \% \text { w/v: } \\
30 \%-10 \% \text { v/v: } 10 \%-30 \% \text { v/v) } \\
90-102 \mathrm{~nm}, 76 \%-79 \% \text { EE }\end{array}$ & $\begin{array}{l}\text { In vitro permeation through } \\
\text { Wistar rat skin under occlusive } \\
\text { application on } 1.76 \mathrm{~cm}^{2} \text {. Atopic } \\
\text { dermatitis was induced by } \\
\text { repeated topical application of } \\
\text { 2,4-dinitrofluorobenzene on } \\
\text { BALB/c mice. }\end{array}$ & $\begin{array}{l}\text { SC deposition was equal for ethosomes and } \\
\text { commercial Protopic. For tacrolimus-ethosomes, } \\
\text { higher drug deposition in epidermis as compared } \\
\text { to liposomes and Protopic was shown. Tacrolimus- } \\
\text { ethosomes with } 30 \% \text { ethanol or } 30 \% \text { PG showed } \\
\text { greater reduction in ear swelling than liposomes, } \\
\text { Protopic, and dexamethasone cream. }\end{array}$ & 120 \\
\hline
\end{tabular}

Notes: Structural properties included size $(\mathrm{nm}), \mathrm{Z}$ potential $(\mathrm{mV})$ and entrapment efficiency (\% EE). Transcutol ${ }^{\circledR}$; Gattefosse SA, Saint Priest, France. Voltaren; Novartis, Basel, Switzerland.

Abbreviations: ALA, 5-aminolevulinic acid; CBD, cannabidiol; EE, entrapment efficiency; EtOH, ethanol; HS, hypertrophic scars; MPB-PE, N-[4-(P-maleimidophenyl)butyryl]phosphatidylethanolamine; PpIX, protoporphyrin IX; SPC, soya phosphatidylcholine; SOD, superoxide dismutase; TEWL, transepidermal water loss; TXG, Taxifolin glycoside; PE, phosphatidylethanolamine; PG, propylene glycol; CDI, immunodeficient mice; ICR, imprinting control region; SC, stratum corneum; TRS, Transfersomes; NaChol, sodium cholate; PEVs, penetration enhancer-containing vesicles; PC, phosphatidylcholine; 5-FU, 5-fluorouracil; Pep-I, cell penetrating peptide Pep-I; Z, zeta; IL, interleukin; IgE, Immunoglobulin E; IFN, Interferon; NC/Nga, inbred stain mice.

well, using hydrophobic pathways in the intercellular lipid matrix of the skin, ${ }^{84}$ because of their suitable lipid-water partition coefficient ${ }^{85}$ and their small size ${ }^{86}$ However, their topical administration in classical topical formulations has limited local action because of their fast clearance from the skin by the capillary plexus underlying the skin surface. ${ }^{84}$ The diclofenac spill-over into the blood circulation leaves too little of the drug in the target organs for adequate standalone therapy. ${ }^{84}$

The biodistribution and plasma pharmacokinetics of a lotion-like formulation of diclofenac in TRS was determined in NMR1 mice, Wistar rats, and common pigs. ${ }^{82}$ Transfenac has an estimated $75 \%$ membrane bound diclofenac and flexibility of the vesicle membrane at least five times higher than that of standard PC vesicles in fluid phase. Transfenac showed a longer effect and reached ten times higher concentrations in the tissues under the skin in comparison with the drug from a commercial hydrogel of diclofenac. These advantages were more pronounced with increased muscle thickness and by decreasing drug dose. This was explained by assuming that the drug associated with carriers is cleared less efficiently by the dermal capillary plexus, that peaks approximately 100-150 $\mu \mathrm{m}$ below the skin surface, ie, within the papillary dermis embracing the upper cutaneous blood plexus. ${ }^{87}$ This is the reason why most of the topical NSAIDs reach a depth of merely a few millimeters, ${ }^{82,84,88}$ the same as for many other topically applied amphipathic drugs. It has been suggested that the regioselectivity of drugs delivered in TRS depends on the drug association with the vesicle bilayer. ${ }^{71}$ The avoidance of drug clearance by the capillary plexus occurs because of the size of TRS ( $\sim 100 \mathrm{~nm}$ diameter), which are too bulky to penetrate through the non-fenestrated capillary of the skin. Because of the absence of irrigation of the cutaneous tissue employed in the in vitro permeation/penetration experiments, it is also believed that Franz-cell experiments are useless for testing the formulations that contain carriers capable of non-diffusive penetration of the skin barrier. The in vitro and in vivo results for the latter kind of formulation can differ by two orders of magnitude. ${ }^{89}$

Topical delivery of diclofenac employing different fluid vesicles is less advanced, but showed similar trends. For example the transdermal permeation of diclofenac either in the acid or in the sodium salt form loaded into Transcutol-containing PEVs was tested in vitro through newborn pig skin. ${ }^{46}$ The PEVs were better carriers than liposomes and commercial diclofenac sodium salt gel formulation for the local delivery of diclofenac to the skin. The high deposition of both drug forms (in particular of acid form, more lipophilic than the sodium salt) into the epidermis suggested that PEVs penetrate the intact skin, reaching the epidermis to form a depot from which the drug is released. More recently, the efficacy of diclofenac-PEVs on phorbol ester-induced skin inflammation was examined. ${ }^{90}$ Diclofenac-PEVs resulted in marked attenuation of edema and leukocyte infiltration and provided an amelioration of 
the tissue damage. In vivo and ex-vivo results indicate that PEVs localized the drug to the site of inflammation, while as diclofenac solution and commercial Voltaren Emulgel ${ }^{\circledR}$ (Novartis, Basel, Switzerland), the drug continues to diffuse across the skin without any control and mostly reaching the systemic circulation from where it is metabolized and excreted.

Ketoprofen is another poorly hydrosoluble $(51 \mathrm{mg} / \mathrm{L}$, $\log \mathrm{P}=3.12$ ), potent analgesic NSAID of the propionic acid group derived from aryl carboxylic acid. By inhibiting COX-2 and COX-1, its side effects are gastrointestinal upset and ulceration. Ketoprofen is thought to have anti-bradykinin activity, as well as lysosomal membrane-stabilizing action. Antipyretic effects may be due to action on the hypothalamus. Identical to topical diclofenac, TRS (Diractin) ${ }^{38,91}$ were successfully used to improve the regioselectivity of ketoprofen. ${ }^{28,78}$ More than $95 \%$ of the total applied drug amount is either bound to or encapsulated into TRS. ${ }^{89}$ The benefit of Diractin showed up only in vivo after nonocclusive topical application. The area under the curve (AUC) for the carriersbased gel in the peripheral deep muscle then exceeds the AUC for a conventional gel by $\sim 35$-fold. Conversely, the occluded TRS have approximately ten times lower AUC. Occlusion thus prevents TRS from showing their superior drug delivery characteristics in vivo compared with a conventional drugin-gel formulation. ${ }^{39}$

Swissmedic approved Diractin in 2006 for the treatment of inflammation and pain related to osteoarthritis based on the first pivotal European study, which demonstrated that both Diractin and an oral COX-2 inhibitor improved pain comparably. In 2008, the European Medicines Agency did not approve Diractin since the efficacy of the drug for the proposed dose was not sufficiently demonstrated. In response, IDEA AG announced in 2009 that Diractin, locally applied ketoprofen-free vesicles, and oral COX-2 inhibitor were superior to oral placebo for the treatment of osteoarthritis of the knee in two Phase III clinical studies. Surprisingly, differences between Diractin and the locally applied ketoprofen-free vesicles were not statistically significant, but they caused lower rates of gastrointestinal adverse events than oral treatment. ${ }^{92}$ However, post hoc analyses revealed Diractin superiority over the empty deformable vesicles in a large subgroup of patients. ${ }^{6,92}$

A preclinical study testing the efficacy of ketoprofen in ethosomes for transdermal drug delivery was recently published. ${ }^{93}$ Improved drug permeation across human skin and higher transdermal flux with ethosomal formulations compared to hydroethanolic drug solution was revealed in vitro. Based on transdermal flux, the estimated steady state in vivo plasma concentration from ethosomes attained therapeutic drug levels, whereas the hydroethanolic drug solution exhibited subtherapeutic drug concentrations with a patch size of $50 \mathrm{~cm}^{2}$.

\section{Preclinical applications as anti- scarring, anti-atopic dermatitis, and anti-psoriasis agents}

A hypertrophic scar (HS) has a different tissue composition from that of normal skin. It lacks mature corneocytes and this leads to SC barrier dysfunction. ${ }^{94} \mathrm{HS}$ tissue also has fewer hair follicles, skin glands, dermal papilla, and other ancillary structures. The dermis of HS is much thicker than that of skin and contains a large number of collagen fibers. ${ }^{95}$ Although the SC of HS is frequently thicker than that of normal skin, most of the corneocytes in HS SC are immature, demonstrating irregular shape and fragility. Scanning electron microscopy of such corneocytes reveals numerous fine wrinkles on their enlarged surface areas that may weaken the SC barrier function. Additionally, the hydrophobic ceramide composition of the HS SC lipids is decreased, ${ }^{94}$ which allows easier penetration of hydrophilic drugs into scar tissues. Overall, scar tissues seriously affect the process of transdermal absorption of both hydrophilic and hydrophobic drugs, ultimately influencing the therapeutic effects for skin scars. ${ }^{96,97}$

A preliminary study tested the in vitro penetration of quantum dots trapped within ethosomes (PC/ethanol $2 \% / 30 \%, 75 \mathrm{~nm}$ ) in human skin HS. ${ }^{98}$ It was found that ethosomes can penetrate into the dermis layer of the scar tissue. However, the occlusion conditions were not reported and the study lacked controls with other liposomes or hydroethanolic solution.

5-fluorouracil (5-FU) possesses anti-scarring activity and is widely recommended in clinical practice, ${ }^{99}$ but its administration route is mainly intralesional injection, which causes severe pain (despite the use of anesthesia). Recently, 5-FU-ethosomes were employed to facilitate its painless delivery into scar tissue. ${ }^{32}$ Previously, the depth of penetration in HS was determined to be size dependent and maximal for $65 \mathrm{~nm}$ diameter ethosomes. ${ }^{100}$ In vitro delivery of 5-FU-ethosomes was more efficient in human HS than in skin and greater than that of 5-FU in hydroethanolic solution. However, though the authors point out that ethosomes could enhance drug penetration in the epidermis and dermis in HS, this preliminary study also lacked elemental controls, such as the comparison with deformable vesicles and the inclusion of cytotoxicity screening on keratinocytes. 
Psoriasis is a chronic inflammatory T-lymphocyte mediated autoimmune disease of the dermis and epidermis characterized by leukocyte infiltration into the skin and localized deregulated skin growth, which leads to the development of scaling erythematous plaques. ${ }^{101}$ Traditional treatments can cause remission of symptoms, with a limited effective outcome. ${ }^{102,103}$ Biologic-immune-response modifiers are under development. ${ }^{104}$ It was recently shown that ALA-mediated PDT can be used to modulate cellular functions, which lead to induction of transcription factors (especially activating protein-1, AP-1, and nuclear factor kappa-light chain enhancer of activated B cells, NF-kB) but cannot induce cell death in psoriasis covering a large area with long-term treatment. ${ }^{105}$ Nonetheless, to increase the ALA permeation across the SC, expensive solutions of ALA at high concentration (20\%) that cause irritation have to be employed. In this frame, the antipsoriatic effect of ALA-mediated PDT by ALA-ethosomes was tested on a psoriatic-like model induced by tape-stripping on mouse skin. ${ }^{106}$ The major differences between human and mouse skin are their relative thickness: human SC are $17 \mu \mathrm{m}$ whereas mouse SC are $9 \mu \mathrm{m}$; and human epidermises are $47 \mu \mathrm{m}$ whereas mouse epidermises are $29 \mu \mathrm{m}$. Further differences in composition and organization of intercellular SC lipids (free fatty acids, cholesterol, long-chain ceramides, and triglycerides), and the distributing density of hair follicles, ${ }^{107}$ account for the higher penetration rates on mice skin. Psoriatic lesions differ from normal skin in abnormal SC stacking, which leads to the formation of scales, reduces the granular layer, elongates the epidermal rete, and enlarges the blood vessels. None of these features, except epidermal rete exist in the mouse model. Considering these differences, it was found that ALA in PE ethosomes induced a higher enhancement ratio (amount of ethosomes/amount of aqueous solution) both on normal skin $\left(5 \mathrm{ng} / \mathrm{cm}^{2}\right)$ and on hyper-proliferative skin $\left(26 \mathrm{ng} / \mathrm{cm}^{2}\right)$. Employing ALA-ethosomes, the PpIX reached the inferior epidermis even in the hyper-proliferative model where the epidermis is twice as thick. Furthermore, the induction of tumor necrosis factor (TFN)- $\alpha$, an inflammatory mediator typical of psoriasis, was reduced.

The incidence of dermatitis, the most common chronic and episodic skin disease characterized with severe itching, has been rising incessantly. ${ }^{108,109}$ Atopic dermatitis (AD) is a chronically relapsing skin disorder characterized by allergic symptoms such as redness, flaking, and itching. ${ }^{110} \mathrm{In} \mathrm{AD}$, there is a dysfunction of the SC that results in excessive transepidermal water losses (TEWL) and infiltration of allergens into the skin. ${ }^{111} \mathrm{~A}$ complex immune dysregulation and environmental allergenic susceptibility are probably both involved in the underlying etiology. The standard treatment of AD is based on the use of topical glucocorticoids, which, with prolonged use at high-doses, cause a variety of adverse effects both systemically and locally on the skin (skin atrophy and telangiectasia). ${ }^{112,113}$ Currently, nonsteroidal immunosuppressive agents like cyclosporin and thymopentin are commonly used as first-line agents in the treatment of AD and skin inflammatory reactions. ${ }^{114}$ Both have a relatively short duration of action and can cause significant side effects with long-term use. In this context, alternative medicines that can be applied safely for longer periods of time are needed.

Recently, the cell penetrating peptide Pep- 1 conjugated to Transfersomes (Pep1-Tr) was employed as a vehicle for 3-O- $\beta$-d-glucopyranoside (Taxifolin $[\mathrm{TXG}]$ ) against 2,4,6-trinitro-1-chloro-benzene-induced atopic dermatitislike lesions in $\mathrm{NC} / \mathrm{Nga}$ (inbred stain mice established from Japanese fancy mice by Kondo [Nagoya University, Nagoya, Japan]) mice. ${ }^{115}$ TXG is a major flavonoid isolated from Rhododendron mucronulatum and Silybum marianum that inhibits microbial antigen-stimulated dendritic-cell mediated allergic responses in a dose-dependent manner. ${ }^{116}$ TXG also reduces serum levels of eosinophils, IgE, IL-4, and IL-5 in $\mathrm{NC} / \mathrm{Nga}$ (inbred stain mice established from Japanese fancy mice by Kondo [Nagoya University, Nagoya, Japan]) mice. However, the topical delivery of TXG to the relevant skin layer is markedly limited because of its hydrophilicity. The cell-penetrating peptides interact with lipids in the SC, thus destabilizing the outermost layer of the skin and enhancing permeability. ${ }^{117,118}$ Conjugation of Pep-1 peptides to TRS remarkably increased the delivery of liposomal drugs into human keratinocytes ( $\mathrm{HaCaT})$ when compared to $\mathrm{Tr}$ alone. ${ }^{119}$ TXG-Pep1-Tr treatment significantly expedited recovery in skin barrier function when compared to animals treated with TXG aqueous solution. Moreover, the formulation normalized multiple immunological parameters including interleukin (IL)-4, immunoglobulin E (IgE), interferon (IFN)- $\gamma$ in NC/Nga mice, with serum levels approaching those of healthy mice.

Finally, the hydrophobic immunosuppressant tacrolimus in ethosomes was tested against a preclinical model of $\mathrm{AD}$ induced by repeated application of the hapten 2,4-dinitrofluorobenzene, in the ears of BALB/c mice. ${ }^{120}$ This mouse strain is susceptible to the $\mathrm{T}$ lymphocyte immune response, showing strong delayed allergic reaction that affects ear thickness. Tacrolimus is a poorly hydrophilic $(4 \mu \mathrm{g} / \mathrm{mL})$, lipophilic $(\log \mathrm{P}=3.3)$ drug molecule with a 23 -member macrolide lactone structure. Tacrolimus produces no skin atrophy, suggesting safety for lesions on the face as well as neck, and showed anti-itch properties. ${ }^{121,122}$ Its ointment, of 
trade name Protopic (Astellas Toyama Co., Ltd., Toyama city, Japan), has neither an effective permeation-enhancing mechanism nor potent penetration enhancers, and therefore showed relatively weaker inhibition efficacy as compared with glucocorticoids. ${ }^{123}$ To enhance the skin penetration of tacrolimus, ethosomes containing different amounts of ethanol and/or the penetration/permeation enhancer PG were prepared. ${ }^{124}$ All ethosomal preparations showed higher drug concentrations in the epidermis in comparison with conventional liposomes and commercial Protopic ointments. $0.1 \%$ tacrolimus-ethosomes potently inhibited mouse ear swelling, substantially impeded hyperplasia of the epidermis and dermis, and reduced the number of dermal mast cells and eosinophils in the ear. It is thought that tacrolimus suppressed antigen-specific T-cell activation responsible for dermatitis and inhibition of inflammatory cytokine release, which mediates immediate and chronic allergic reactions through mechanisms such as IgE production, eosinophil activation, and macrophage recruitment. Tacrolimus can deplete the content of substance P (a neuropeptide released from sensory nerve fibers, which potentiates inflammation through mast cell activation). Since mechanisms involving T-cells and substance $\mathrm{P}$ are located in the dermis, the finding in the present study of a higher amount of tacrolimus in ethosomes in deeper skin layers is consistent with the greater inhibition of 2,4-dinitrofluorobenzene effects, compared with Protopic. In contrast, glucocorticoids suppress immune inflammation by interacting with various transcription factors such as $\mathrm{NF}-\mathrm{\kappa B}$ and AP-1, which activate transcription of genes for inflammatory cytokines and enzymes. ${ }^{125}$ As tacrolimus works selectively on T-cells, it would be expected to be associated with fewer side effects, especially when applied topically.

\section{Conclusion}

Topical therapy of NMSC presents a remarkable opportunity to introduce deformable/fluid vesicles as carriers of antitumoral drugs in oncology. But, in spite of its strategic importance, the studies based exclusively on ethosomes are scarce; the antitumoral efficacy is yet to be tested on adequate preclinical models and contrasted to that of Transfersomes. The absence of Transfersomes in this field could be attributed to difficulties of loading highly hydrophobic drugs to their bilayers without affecting their deformability. In terms of entrapment efficiency, the highly fluid bilayers of the ethosomes, having a multi-bilayer structure and inner hydroethanolic multi-compartments, would have an advantage over highly deformable vesicles. Nonetheless, since Transfersomes penetrate instead of permeate the skin layers, assessing the impact of a low dose/area of hydrophobic antitumoral drugs in vesicles with highly deformable bilayers on NMSC would be of interest. A second big challenge is represented by the delivery of anti-inflammatory agents against a variety of skin pathologies. This relatively well explored area requires formulations enabling repeated applications without altering the permeability barrier of the SC. Here, the skin structure could be better preserved by highly deformable vesicles over those bilayers that include permeation enhancers.

\section{Disclosure}

The authors report no conflicts of interest in this work.

\section{References}

1. Bangham AD, Horne RW. Negative staining of phospholipids and their structured modofication by surface active agents as observed in the electron microscope. J Mol Biol. 1964;8:660-668.

2. Black CD, Watson GJ, Ward RJ. The use of Pentostam liposomes in the chemotherapy of experimental leishmaniasis. Trans $R$ Soc Trop Med Hyg. 1977;71:550-552.

3. Iyer AK, Khaled G, Fang J, Maeda H. Exploiting the enhanced permeability and retention effect for tumor targeting. Drug Discov Today. 2006;11:812-818.

4. Lehtinen J, Magarkar A, Stepniewski M, et al. Analysis of cause of failure of new targeting peptide in PEGylated liposome: molecular modeling as rational design tool for nanomedicine. Eur J Pharm Sci. 2012;46:121-130.

5. Cevc G, Schätzlein A, Gebauer D, Blume G. Ultra-high efficiency of drug and peptide transfer through the intact skin by means of novel drug-carriers, Transfersomes. In: Bain KR, Hadgkraft J, James WJ, Water KA, editors. Prediction of Percutaneous Penetration. Vol 3b. Cardiff: STS Publishing; 1993:226-234.

6. Cevc G. Rational design of new product candidates: the next generation of highly deformable bilayer vesicles for noninvasive, targeted therapy. J Control Release. 2012;160:135-146.

7. Kumar A, Pathak K, Bali V. Ultra-adaptable nanovesicular systems: a carrier for systemic delivery of therapeutic agents. Drug Discov Today. 2012;17:1233-1241.

8. Cevc G, Vierl U, inventors. Idea Ag, assignee. NSAID formulations, based on highly adaptable aggregates, for improved transport through barriers and topical drug delivery. United Sates patent US7473432 B2. 2009 Jan 6.

9. Cevc G, Vierl U, inventors. Idea Ag, assignee. Aggregates with increased deformability, comprising at least three amphipats, for improved transport through semi-permeable barriers and for the non-invasive drug application in vivo, especially through the skin. United Sates patent US20090155235 A1. 2009 Jun 18.

10. Elsayed MM, Cevc G. The vesicle-to-micelle transformation of phospholipid- cholate mixed aggregates: a state of the art analysis including membrane curvature effects. Biochim Biophys Acta. 2011;1808: $140-153$.

11. Cevc G. Material transport across permeability barriers by means of lipid vesicles. In: Lipowsky R, Sackmann E, editors. Handbook of Biological Physics. Vol I. Elsevier Science B.V; 1995: 465-489.

12. Cevc G, Vierl U. Nanotechnology and the transdermal route. A state of the art review and critical appraisal. J Control Release. 2010;141: 277-299.

13. Boncheva M, de Sterke J, Caspers PJ, Puppels GJ. Depth profiling of stratum corneum hydration in vivo: a comparison between conductance and confocal Raman spectroscopic measurements. Exp Dermatol. 2009; 18:870-876. 
14. Warner RR, Lilly NA. Correlation of Water Content with Ultrastructure in the Stratum Corneum, In: Friedrich-Schiller PE, Berardesca E, Maibach HI, editors. Bioengineering of the Skin. Water and the Stratum Corneum, Volume I. Dermatology: Clinical \& Basic Science Part No. 6. Boca Raton, FL: Informa Healthcare; 1994:3-12.

15. Cevc G, Blume G. Lipid vesicles penetrate into intact skin owing to the transdermal osmotic gradients and hydration force. Biochim Biophys Acta. 1992;1104:226-232.

16. Cevc G, Gebauer D. Hydration-Driven transport of deformable lipid vesicles through fine pores and the skin barrier. Biophys J. 2003;84: 1010-1024.

17. Cevc G, Blume G, Schtitzlein A, Gebauer D, Paul A. The skin: a pathway for systemic treatment with patches and lipid-based agent carriers. $A d v$ Drug Del Rev. 1996;18(3):349-378.

18. Schreier H, Bouwstra J. Liposomes and niosomes as topical drug carriers: dermal and transdermal drug delivery. $J$ Control Release. 1994;30(1):1-15.

19. Mitragotri S. Modeling skin permeability to hydrophilic and hydrophobic solutes based on four permeation pathways. J Control Release. 2003;86:69-92.

20. Mitragotri S. A theoretical analysis of permeation of small hydrophobic solutes across the stratumcorneumbased on scaled particle theory. $J$ Pharm Sci. 2002;91:744-752.

21. Schätzlein A, Cevc G. Non-uniform cellular packing of the stratum corneum and permeability barrier function of intact skin: a high-resolution confocal laser scanning microscopy study using highly deformable vesicles (Transfersomes). Br J Dermatol. 1998;138:583-592.

22. Cevc G, Schätzlein A, Richardsen H. Ultradeformable lipid vesicles can penetrate the skin and other semi-permeable barriers unfragmented. Evidence from double label CLSM experiments and direct size measurements. Biochim Biophys Acta. 2002;1564:21-30.

23. Cevc G, Inventor. Cevc, G assignee. Optimised preparations of highly adaptable aggregates. PCT/EP2012/055040. 2012 Sep 27.

24. Cevc G, Inventor. Cevc, G assignee Drug-free compositions and methods for diminishing peripheral inflammation and pain. PCT/ EP2012/055039. 2012 Sep 27.

25. van den Bergh BAI, Vroom J, Gerritsen H, Junginger HE, Bouwstra JA. Interactions of elastic and rigid vesicles with human skin in vitro: electron microscopy and two- photon excitation microscopy. Biochim Biophys Acta. 1999;1461:155-173.

26. Honeywell-Nguyen PL, de Graaff A, Junginger HE, Wouter Groenink HW, Bouwstra JA. The in vivo and in vitro interactions of elastic and rigid vesicles with human skin. BBActa. 2002;1573:130-140.

27. Honeywell-Nguyen PL, Bouwstra Joke A. The in vitro transport of pergolide from surfactant-based elastic vesicles through human skin: a suggested mechanism of action. J Control Release. 2003;86: $145-156$.

28. Touitou E, Inventor. Compositions for applying active substances to or through the skin. United Sates patent 5,540,934. 1996 Jul 30.

29. Touitou E, Inventor. Yissum Research Development Company of The Hebrew University of Jerusalem, Jerusalem, Israel assignee. Composition for applying active substances to or through the skin. United Sates patent 5,716,638. 1998 Feb 10.

30. Chin JM, Goldstein DB. Membrane disordering action of ethanol: variation with membrane cholesterol content and depth of the spin label probe. Mol Pharmacol. 1981;19(3):425-431.

31. Harris RA, Burnett R, McQuiilkin S, McCloud A, Simon FR. Effect of ethanol on membrane order: fluorescence studies. Ann N Y Acad Sci. 1987;492:125-135.

32. Zhang Z, Wo Y, Zhang Y, et al. In vitro study of ethosome penetration in human skin and hypertrophic scar tissue. Nanomedicine. 2012;8: 1026-1033.

33. Touitou E, Godin B, Weiss C. Enhanced delivery of drugs into and across the skin by ethosomal carriers. Drug Dev Res. 2000;50:406-415.

34. Touitou E, Dayan N, Bergelson L, Godin B, Eliaz M. Ethosomes - novel vesicular carriers for enhanced delivery: characterization and skin penetration properties. J Control Rel. 2000;65:403-418.
35. Blume A, Jansen M, Ghyczy M, Gareis J. Interaction of phospholipid liposomes with lipid model mixtures for stratum corneum lipids. Int $J$ Pharm. 1993;99:219-228.

36. Van der Merwe D, Riviere JE. Comparative studies on the effects of water, ethanol and water/ethanol mixtures on chemical partitioning into porcine stratum corneum and silastic membrane. Toxicol In Vitro. 2005;19:69-77.

37. Cevc G. Lipid vesicles and other colloids as drug carriers on the skin. Adv Drug Del Rev. 2004;56:675-711.

38. Cevc G, Mazgareanu S, Rother M. Preclinical characterisation of NSAIDs in ultradeformable carriers or conventional topical gels. Int J Pharm. 2008;360:29-39.

39. Cevc G, Mazgareanu S, Rother M, Vierl U. Occlusion effect on transcutaneous NSAID delivery from conventional and carrier-based formulations. Int J Pharm. 2008;359:190-197.

40. Bahia AP, Azevedo EG, Ferreira LAM, Frézard F. New insights into the mode of action of ultradeformable vesicles using calcein as hydrophilic fluorescent marker. Eur J Pharm Sci. 2010;39:90-96.

41. Elsayed MM, Abdallah OY, Naggar VF, Khalafallah NM. Deformable liposomes and ethosomes: mechanism of enhanced skin delivery. Int $J$ Pharm. 2006;322:60-66.

42. Verma DD. Invasomes-Novel Topical Carriers for Enhanced Topical Delivery: Characterization and Skin Penetration Properties. [PhD thesis] Marburg/ Lahn 2002.

43. Verma DD, Verma S, McElwee KJ, Freyschmidt-Paul P, Fahr A. Treatment of alopecia areata in the DEBR model using cyclosporin A lipid vesicles. Eur J Dermatol. 2004;14:332-338.

44. Ntimenou V, Fahr A, Antimisiaris SG. Elastic vesicles for transdermal drug delivery of hydrophilic drugs: a comparison of important physicochemical characteristics of different vesicle types. $J$ Biomed Nanotechnol. 2012;8:613-623.

45. Manconi M, Mura S, Sinico C, Fadda AM, Vila AO, Molina F. Development and characterization of liposomes containing glycols as carriers for diclofenac. Colloids and Surfaces A: Physicochem. Eng Aspects. 2009;342:53-58.

46. Manconi M, Caddeo C, Sinico C, et al. Ex vivo skin delivery of diclofenac by transcutol containing liposomes and suggested mechanism of vesicle-skin interaction. Eur J Pharm Biopharm. 2011;78: $27-35$.

47. Trakatelli M, Ulrich C, del Marmol V, Euvrard S, Stockfleth E, Abeni D. Epidemiology of nonmelanoma skin cancer (NMSC) in Europe: accurate and comparable data are needed for effective public health monitoring and interventions. Br J Dermatol. 2007;156 Suppl 3:1-7.

48. Kim RH, Armstrong AW. Nonmelanoma skin cancer. Dermatol Clin. 2012;30:125-139.

49. Rogers HW, Weinstock MA, Harris AR, et al. Incidence estimate of nonmelanoma skin cancer in the United States, 2006. Arch Dermatol. 2010;146:283-287.

50. Cheng KW, Mattheolabakis G, Wong CC, et al. Topical phosphosulindac (OXT-328) is effective in the treatment of non-melanoma skin cancer. Int J Oncol. 2012;41:1199-1203.

51. Lau KG, Hattori Y, Chopra S, et al. Ultra-deformable liposomes containing bleomycin: in vitro stability and toxicity on human cutaneous keratinocyte cell lines. Int J Pharm. 2005;300:4-12.

52. Hiruta Y, Hattori Y, Kawano K, Obata Y, Maitani Y. Novel ultra-deformable vesicles entrapped with bleomycin and enhanced to penetrate rat skin. J Control Release. 2006;113:146-154.

53. Qiu Y, Gao Y, Hu K, Li F. Enhancement of skin permeation of docetaxel: a novel approach combining microneedle and elastic liposomes. $J$ Control Release. 2008;129:144-150.

54. Paolino D, Celia C, Trapasso E, Cilurzo F, Fresta M. Paclitaxel-loaded ethosomes $\AA$ : potential treatment of squamous cell carcinoma, a malignant transformation of actinic keratoses. Eur J Pharm Biopharm. 2012;81:102-112

55. Hosmer JM, Shin SH, Nornoo A, Zheng H, Lopes LB. Influence of internal structure and composition of liquid crystalline phases on topical delivery of paclitaxel. J Pharm Sci. 2011;100:1444-1455. 
56. Panchagnula R, Desu H, Jain A, Khandavilli S. Effect of lipid bilayer alteration on transdermal delivery of a high-molecular-weight and lipophilic drug: studies with paclitaxel. J Pharm Sci. 2004;93:2177-2183.

57. Crosasso P, Ceruti M, Brusa P, Arpicco S, Dosio F, Cattel L. Preparation, characterization and properties of sterically stabilized paclitaxelcontaining liposomes. J Control Release. 2000;63:19-30.

58. Fang JY, Tsai Y-H, Wu P-C, Huang YB. Comparison of 5-aminolevulinic acid-encapsulated liposome versus ethosome for skin delivery for photodynamic therapy. Int J Pharm. 2008;356:144-152.

59. De Rosa FS, Bentley MV. Photodynamic therapy of skin cancers: sensitizers, clinical studies and future directives. Pharm Res. 2000;17: 1447-1455.

60. Henderson BW, Dougherty TJ. How does photodynamic therapy work? Photochem Photobiol. 1992;55:145-157.

61. Szeimies RM, Morton CA, Sidoroff A, Braathen LR. Photodynamic therapy for non-melanoma skin cancer. Acta Derm Venereol. 2005;85: 483-490.

62. Peng Q, Warloe T, Berg K, et al. 5-Aminolevulinic acid-based photodynamic therapy. Cancer. 1997;79:2282-2308.

63. Yatvin MB, Lelkes PI. Clinical prospects for liposomes. Med Phys. 1982;9:149-175.

64. Barry BW. Novel mechanisms and devices to enable successful transdermal drug delivery. Eur J Pharm Sci. 2001;14:101-114.

65. Fang JY, Hwang TL, Huang YL. Liposomes as vehicles for enhancing drug delivery via skin routes. Curr Nanosci. 2006;2:55-70.

66. Dragicevic-Curic N, Scheglmann D, Albrecht V, Fahr A. Temoporfinloaded invasomes: development, characterization and in vitro skin penetration studies. J Control Release. 2008;127:59-69.

67. Dragicevic-Curic N, Grafe S, Albrecht V, Fahr A. Topical application of temoporfin-loaded invasomes for photodynamic therapy of subcutaneously implanted tumours in mice: a pilot study. $J$ Photochem Photobiol B. 2008;91:41-50.

68. Dragicevic-Curic N, Scheglmann D, Albrecht V, Fahr A. Development of different temoporfin-loaded invasomes - novel nanocarriers of temoporfin: characterization, stability and in vitro skin penetration studies. Colloids Surf B Biointerfaces. 2009;70:198-206.

69. Dragicevic-Curic N, Gräfe S, Gitter B, Fahr A. Efficacy of temoporfinloaded invasomes in the photodynamic therapy in human epidermoid and colorectal tumour cell lines. J Photochem Photobiol B. 2010;101: 238-250.

70. Dragicevic-Curic N, Grafe S, Gitter B, Winter S, Fahr A. Surface charged temoporfin-loaded flexible vesicles: in vitro skin penetration studies and stability. Int J Pharm. 2010;384:100-108.

71. Cevc G, Blume G, Schatzlein A. Transfersomes-mediated transepidermal delivery improves the regio- specificity and biological activity of corticosteroids in vivo. J Control Release. 1997;45:211-226.

72. Cevc G, Blume G. Biological activity and characteristics of triamcinolone-acetonide formulated with the self-regulating drug carriers, Transfersomes. Biochim Biophys Acta. 2003;1614:156-164.

73. Cevc G, Blume G. Hydrocortisone and dexamethasone in very deformable drug carriers have increased biological potency, prolonged effect, and reduced therapeutic dosage. Biochim Biophys Acta. 2004;1663:61-73.

74. Davis AF, Hadgraft J. Effect of supersaturation on membrane transport: 1. Hydrocortisone acetate. Int J Pharm. 1991;76:1-8.

75. Liapi C, Chrousos GP. Glucocorticoids. In: Jaffe SJ, Aranda JV, editors. Pediatric Pharmacology Therapeutic Principles in Practice. 2nd ed. Philadelphia: Saunders; 1992:466-475.

76. Warner RR, Myers MC, Taylor DT. Electron probe analysis of human skin determination of the water concentration profile. J Invest Dermatol. 1988;90:218- 224.

77. Fesq H, Glöckner D, Abeck D, et al. Improved risk-benefit ratio for a triamcinolone acetonide TransfersomeR formulation in comparison to a commercial triamcinolone acetonide formulation. $\mathrm{Br} J$ Dermatol. 2003;149:611-619.

78. Reynolds JIF, editor. The Extra Pharmacopoeia (Martindale). London: The Pharmaceutical Press; 1993;620-637.
79. Lodzkia M, Godina B, Rakoua L, Mechoulamb R, Gallilyc R, Touitou E. Cannabidiol - transdermal delivery and anti-inflammatory effect in a murine model. J Control Release. 2003;93:377-387.

80. Paolino D, Lucania G, Mardente D, Alhaique F, Fresta M. In vitro percutaneous permeation through human skin and in vivo antiinflammatory activity on human volunteers. $J$ Control Release. 2005;106:99-110.

81. Simoes SI, Delgado TC, Lopes RM, et al. Developments in the rat adjuvant arthritis model and its use in therapeutic evaluation of novel non-invasive treatment by SOD in Transfersomes. J Control Release. 2005;103:419-434.

82. Cevc G, Blume G. New, highly efficient formulation of diclofenac for the topical, transdermal administration in ultradeformable drug carriers, Transfersomes. Biochim Biophys Acta. 2001;1514:191-205.

83. Todd PA, Sorkin EM. Diclofenac sodium. A reappraisal of its pharmacodynamic and pharmacokinetic properties and therapeutic efficacy. Drugs. 1988;35:244-285.

84. Singh P, Roberts MS. Skin permeability and local tissue concentrations of non-steroidal anti-infammatory drugs after topical application. $J$ Pharmacol Exp Ther. 1994;268:144-151.

85. Hadgraft J, de Plessis J, Goosen C. The selection of non-steroidal anti-inflammatory agents for dermal delivery. Int J Pharm. 2000;207: 31-37.

86. Mitragotri S, Johnson ME, Blankschtein D, Langer R. An analysis of the size selectivity of solute partitioning, diffusion, and permeation across lipid bilayers. Biophys J. 1999;77:1268-1283.

87. Braverman IM. The cutaneous microcirculation: ultrastructure and microanatomical organization. Microcirculation. 1997;4:329-340.

88. Monteiro-Riviere NA, Inman AO, Riviere JE, McNeil SC. Topical penetration of piroxicam is dependent on the distribution of the local cutaneous vasculature. Pharm Res. 1993;10:1326-1331.

89. Cevc G, Vierl U, Mazgareanu S. Functional characterisation of novel analgesic product based on self-regulating drug carriers. Int J Pharm. 2008;360:18-28.

90. Caddeo C, Diez Sales O, Valentia D, Ruiz Saurí A, Fadda AM, Manconi M. Inhibition of skin inflammation in mice by diclofenac in vesicular carriers: liposomes, ethosomes and PEVs. Int J Pharm. 2013; 443:128-136.

91. Cevc G, Vierl U, Inventors. Idea Ag, assignee. Aggregates with increased deformability, comprising at least three amphiphats, for improved transport through semi-permeable barriers and for the non-invasive drug application in vivo, especially through the skin. European Patent EP1551370 A1. 2005 Jul 13.

92. Rother M, Cevc G. IDEA updates on Diractin ${ }^{\circledR}$ (ketoprofen in Transfersome $^{\circledR}$ gel) status. Munich: IDEA AG; 2009. Available from: http://www. technostart.com/down/r_d_2_091007_PR_Diractin.pdf. March, 2013.

93. Chourasia MK, Kang L, Chan SY. Nanosized ethosomes bearing ketoprofen for improved transdermal delivery. Results Pharma Sci. 2011;1:60-67.

94. Kunii T, Hirao T, Kikuch K, Tagami H. Stratum corneum lipid profile and maturation pattern of corneocytes in the outermost layer of fresh scars: the presence of immature corneocytes plays a much more important role in the barrier dysfunction than do changes in intercellular lipids. Br J Dermatol. 2003;149:749-756.

95. Sogabe Y, Akimoto S, Abe M, Ishikawa O, Takagi Y, Imokawa G. Functions of the stratum corneum in systemic sclerosis as distinct from hypertrophic scar and keloid functions. J Dermatol Sci. 2002;29:49-53.

96. Zurada JM, Kriegel D, Davis IC. Topical treatments for hypertrophic scars. Am Acad Dermatol. 2006;55:1024-1031.

97. Chung V, Kelley L, Marra D, Jiang SB. Onion extract gel versus petrolatum emollient on new surgical scars: prospective double-blinded study. Dermatol Surg. 2006;32:193-198.

98. He R, Cui D-X, Gao F. Preparation of fluorescence ethosomes based on quantum dots and their skin scar penetration properties. Mater Lett. 2009;63:1662-1664. 
99. Hatamipour E, Mehrabi S, Hatamipour M, Ghafarian Shirazi HR. Effects of combined intralesional 5-fluorouracil and topical silicone in prevention of keloids: a double blind randomized clinical trial study. Acta Med Iran. 2011;49:127-130.

100. Mao XH, Wo Y, He R, Qian YL, Zhang YX, Cui DX. Preparation and characterization of different sizes of ethosomes encapsulated with 5-fluorouracil and its experimental study of permeability in hypertrophic scar. J Nanosci Nanotechnol. 2010;10:4178-4183.

101. Lowes MA, Bowcock AM, Krueger JG. Pathogenesis and therapy of psoriasis. Nature. 2007;445:866-873.

102. Witman PM. Topical therapies for localized psoriasis. Mayo Clin Proc. 2001;76:943-949.

103. Schön MP, Boehncke WH. Psoriasis. N Engl J Med. 2005;18: 1899-1912.

104. Gottlieb AB. Psoriasis: emerging therapeutic strategies. Nat Rev Drug Discov. 2005;4:19-34.

105. Klein A, Babilas P, Karrer S, Landthaler M, Szeimies RM. Photodynamic therapy in dermatology - an update. J Dtsch Dermatol Ges. 2008;6:839-845.

106. Fang Y-P, Huang Y-B, Wua P-C, Tsai Y-H. Topical delivery of 5-aminolevulinic acid-encapsulated ethosomes in a hyperproliferative skin animal model using the CLSM technique to evaluate the penetration behavior. Eur J Pharm Biopharm. 2009;73:391-398.

107. Godin B, Touitou E. Transdermal skin delivery: predictions for humans from in vivo, ex vivo and animal models. Adv Drug Deliv Rev. 2007: 1152-1161.

108. Tanaka Y. Pathogenesis and guidelines for therapy of atopic dermatitis. Nihon Rinsho. 2001;59:1219-1227.

109. Wahlgren CF. Pathophysiology of itching in urticaria and atopic dermatitis. Allergy. 1992;47:65-75.

110. Leung DY, Bieber T. Atopic dermatitis. Lancet. 2003;361:151-160.

111. Watanabe M, Tagami H, Horii I, Takahashi M, Kligman AM. Functional analyses of the superficial stratum corneum in atopic xerosis. Arch Dermatol. 1991;127:1689-1692.

112. Barnetson RS, White AD. The use of corticosteroids in dermatological practice. Med J Aus. 1992;156:428-431.
113. Leung AK, Barber KA. Managing childhood atopic dermatitis. Adv Ther. 2003;20:129-137.

114. Lee O, Choi M, Ha S, et al. Effect of pedunculagin investigated by non-invasive evaluation on atopic-like dermatitis in NC/Nga mice. Skin Res Technol. 2010;16:371-377.

115. Kang MJ, Eum JY, Park SH, et al. Pep-1 peptide-conjugated elastic liposomal formulation of taxifolin glycoside for the treatment of atopic dermatitis in NC/Nga mice. Int J Pharm. 2010;402:198-204.

116. Kim YJ, Choi SE, Lee MW, Lee CS. Taxifolin glycoside inhibits dendritic cell responses stimulated by lipopolysaccharide and lipoteichoic acid. J Pham Pharmacol. 2008;60:1465-1472.

117. Hou YW, Chan MH, Hsu HR, et al. Transdermal delivery of proteins mediated by non-covalently associated arginine-rich intracellular delivery peptides. Exp Dermatol. 2007;16:999-1006.

118. Lopes LB, Brophy CM, Furnish E, et al. Comparative study of the skin penetration of protein transduction domains and a conjugated peptide. Pharm Res. 2005;22:750-757.

119. Kang MJ, Kim BG, Eum JY, et al. Design of a Pep-1 peptide-modified liposomal nanocarrier system for intracellular drug delivery: conformational characterization and cellular uptake evaluation. J Drug Target. 201;19:497-505.

120. Li G, Fan Y, Fan C, et al. Tacrolimus-loaded ethosomes: physicochemical characterization and in vivo evaluation. Eur J Pharm Biopharm. 2012;82:49-57.

121. Bieber T. Topical tacrolimus (FK 506): a new milestone in the management of atopic dermatitis. J Allergy Clin Immunol. 1998;102: 555-557.

122. Nakagawa H, Etoh T, Ishibashi Y, et al. Tacrolimus ointment for atopic dermatitis. Lancet. 1994;344:883.

123. Inagaki $\mathrm{N}$, Shiraishi $\mathrm{N}$, Igeta $\mathrm{K}$, et al. Inhibition of scratching behavior associated with allergic dermatitis in mice by tacrolimus, but not by dexamethasone. Eur J Pharmacol. 2006;546:189-196.

124. Williams AC. Transdermal and Topical Drug Delivery; from theory to clinical practice. London: Pharmaceutical Press; 2003.

125. Jacobs MD, Harrison SC. Structure of an IkappaBalpha/NF-kappaB complex. Cell. 1998;95:749-758.
International Journal of Nanomedicine

\section{Publish your work in this journal}

The International Journal of Nanomedicine is an international, peerreviewed journal focusing on the application of nanotechnology in diagnostics, therapeutics, and drug delivery systems throughout the biomedical field. This journal is indexed on PubMed Central, MedLine, CAS, SciSearch ${ }^{\circledR}$, Current Contents ${ }^{\circledR} /$ Clinical Medicine,

\section{Dovepress}

Journal Citation Reports/Science Edition, EMBase, Scopus and the Elsevier Bibliographic databases. The manuscript management system is completely online and includes a very quick and fair peer-review system, which is all easy to use. Visit http://www.dovepress.com/ testimonials.php to read real quotes from published authors. 